\title{
Soil Nitrogen Sorption Using Charcoal and Wood Ash
}

\author{
Nur Hidayah Hamidi ${ }^{1}\left(\mathbb{D}\right.$, Osumanu Haruna Ahmed $\left.{ }^{1,2,3, *} \mathbb{(}\right)$, Latifah Omar ${ }^{1,2}$ and Huck Ywih Ch'ng ${ }^{4}(\mathbb{D}$ \\ 1 Department of Crop Science, Faculty of Agricultural Science and Forestry, Bintulu Campus, \\ Universiti Putra Malaysia, Bintulu 97008, Malaysia; dayahmidi@gmail.com (N.H.H.); \\ latifahomar@upm.edu.my (L.O.) \\ 2 Institut Ekosains Borneo, Sarawak Campus, Universiti Putra Malaysia Bintulu, Bintulu 97008, Malaysia \\ 3 Institute of Tropical Agriculture and Food Security, Universiti Putra Malaysia, Serdang 43400, Malaysia \\ 4 Faculty of Agro-Based Industry, Campus Jeli, University Malaysia Kelantan, Jeli 17600, Malaysia; \\ huckywih@umk.edu.my \\ * Correspondence: osumanu@upm.edu.my; Tel.: +60-19-369-5095
}

Citation: Hamidi, N.H.;

Ahmed, O.H.; Omar, L.; Ch'ng, H.Y. Soil Nitrogen Sorption Using Charcoal and Wood Ash. Agronomy 2021, 11, 1801. https://doi.org/ 10.3390/agronomy11091801

Academic Editors: Alwyn Williams and Baskaran Stephen Inbaraj

Received: 3 May 2021

Accepted: 6 July 2021

Published: 8 September 2021

Publisher's Note: MDPI stays neutral with regard to jurisdictional claims in published maps and institutional affiliations.

Copyright: (c) 2021 by the authors. Licensee MDPI, Basel, Switzerland. This article is an open access article distributed under the terms and conditions of the Creative Commons Attribution (CC BY) license (https:// creativecommons.org/licenses/by/ $4.0 /)$.

\begin{abstract}
This paper reviews the use of charcoal and wood ash in acid soils as adsorbents to improve $\mathrm{N}$ availability at the same time improving their soil fertility and crop productivity. Soil acidification poses a major challenge in agricultural sustainability and it is serious in highly weathered soils such as Ultisols and Oxisols which are noted for nutrient deficiency and $\mathrm{Al}$ and Fe ions toxicities. Understanding sorption mechanisms and isotherms is important for the improvement of soil $\mathrm{N}$ availability particularly inorganic N. However, understanding the sorption mechanisms in relation to charcoal and wood ash as absorbents in the literature is difficult because the soil amendments vary depending on their raw materials or sources of origin. Therefore, one of the objectives of this review is to provide recent research findings and theory development on the role of charcoal and wood ash in agriculture. Furthermore, this review focuses on how charcoal and wood ash improve $\mathrm{N}$ availability through physical, chemical and biological processes in mineral acidic soils. Balanced application and good understanding of the role of charcoal and wood ash as soil amendments have potential benefits to improve $\mathrm{N}$ availability and crop productivity.
\end{abstract}

Keywords: nitrogen mineralization; nitrogen availability; organic amendments; mechanisms; soil acidity

\section{Introduction}

Views have been expressed that by 2050 , approximately $70 \%$ to $100 \%$ increase in the worldwide agricultural production will be needed to feed nine billion people in the world [1]. To achieve the world-wide sustainable food supply that can cope with the rapid urbanisation and growth of the human population, optimum use of fertilisers is essential [2]. Anthropogenic activities such as rapid industrialisation and intensive agricultural production with substantial amount of $\mathrm{N}$ fertilisation causes losses of $\mathrm{C}$ and $\mathrm{N}$ to the environment [3]. Nitrogen fertilisers are highly mobile in soils and because of this, they should be carefully used in agriculture to avoid losses through volatilisation, denitrification and leaching [4]. Poor synchrony of fertiliser nutrient release for timely uptake by plants also contributes to significant loss of N-based fertilisers in most farming systems. Moreover, high temperature and heavy rainfall cause poor nutrient use efficiency in highly weathered acid soils. These activities lead to low nutrient content and rapid mineralisation of soil organic matter [5]. Soil acidification poses a major challenge to agricultural sustainability [6]. This problem is particularly serious in highly weathered soils whose supply of most plant nutrients apart from $\mathrm{Fe}, \mathrm{Al}$, and $\mathrm{Mn}$ ions decrease with increasing $\mathrm{pH}$. For example, as base cations such as $\mathrm{K}, \mathrm{Ca}, \mathrm{Mg}$, and $\mathrm{Na}$ acquire leached from highly weathered soils, these nutrients including $\mathrm{NH}_{4}$ and $\mathrm{NO}_{3}$ ions are replaced by $\mathrm{Fe}, \mathrm{Al}$, and $\mathrm{Mn}$ ions. In addition to loss of organic matter, and Fe and $\mathrm{Al}$ hydrolysis result in further soil acidification which decreases soil productivity. 
Approximately $90 \%$ of the soil total $\mathrm{N}$ is composed of organic $\mathrm{N}$ which plays an important role in $\mathrm{N}$ transformation and retention [7]. In addition, approximately $90 \%$ of the $\mathrm{N}$ fertilisers in the world is in the inorganic form $\left(\mathrm{NH}_{4}{ }^{+}\right)$. The ammonium ions are transformed into highly mobile $\mathrm{NO}_{3}{ }^{-}$and $\mathrm{NO}_{2}{ }^{-}$by nitrifying bacteria under aerobic conditions in soils [8]. Nitrogen leaching and runoff do not only reduce nutrient uptake efficiency, but also cause serious environmental pollution such as eutrophication [8]. One of the approaches to solve this problem is controlling the dissolution and hydrolysis of $\mathrm{N}$ fertilisers such as urea, ammonium nitrate, ammonium sulphate, among others. This practice controls the availability of urea- $\mathrm{N}$ by reducing the microsite $\mathrm{pH}$ with acid materials such as acidic phosphates and phosphoric acid $[9,10]$. However, these materials are expensive and corrosive.

Another approach to minimise nutrient losses is through for example, treating poultry manure which is co-composted with rice husk bio-charcoal (RHC). This RHC is able to reduce $\mathrm{N}$ losses because it traps organic and inorganic nutrients such as $\mathrm{C}, \mathrm{N}, \mathrm{P}$ and $\mathrm{K}$ to prevent them from being leached from soils [11]. However, this method is time consuming. Thus, efforts are on-going to increase the ability of organic amendments, not only for improving soil productivity but also to improve chemical fertilisers use efficiency [12]. The use of composts, manures, and mulches has proven to improve soil fertility. However, in the tropics, organic matter mineralises rapidly [13] and only a small amount of the organic matter applied is stabilised in soils for a long period [14]. Therefore, it is essential to control $\mathrm{N}$ losses to enhance $\mathrm{N}$ retention using inexpensive, reliable, and environmentally friendly methods, one of which is using charcoal and wood ash.

Charcoal is a solid carbonaceous residue which is produced by heating through slow and rapid pyrolysis, gasification, and hydrothermal carbonisation under oxygen-deficient conditions [15]. Charcoal is produced through slow pyrolysis [16] and it is highly resistant to decomposition $[17,18]$. Charcoal in soils does not only influence the nature of sorption mechanism but it also improves sorption of organic pollutant $[19,20]$. Charcoal can play an important role in soil physical, chemical and biological processes at least for the first few decades after its formation $[17,21,22]$. In carbonaceous materials, adsorption is regulated by physical and chemical structures [20]. Adsorption is commonly used as an efficient physical separation mechanism to remove or reduce the concentration of several dissolved contaminants whether organic or inorganic pollutants [23]. The charcoal structure reflects the morphology of the raw material used [24]. A typical charcoal consists of C, H, N, S, ash, and oxygen [25]. In addition, its structure, composition, and characteristics such as particle size distribution, moisture content, density, ash content, and $\mathrm{pH}$ depend on the form, nature and origin of raw material, along with the state of thermal conversion cycle [26]. Charcoal is made up of several inorganic and organic forms of $\mathrm{N}$ and $\mathrm{P}$, such as $\mathrm{NO}_{3}{ }^{-}, \mathrm{NH}_{4}{ }^{+}$, amide groups and ortho-P $[27,28]$. However, the concentrations of these nutrients depend on production temperature and source of the charcoal. For example, charcoal produced at lower temperature have more $\mathrm{NH}_{4}{ }^{+}$, whereas charcoal produced at higher temperature tends to have more $\mathrm{NO}_{3}{ }^{-}$. Charcoal produced from plant residues usually has higher nutrients than charcoal which is generated from ligno-cellulosic raw materials [29]. The contents of the nutrients, and the conservation of nutrients can be enhanced by applying charcoal to soils. This is particularly relevant in heavily weathered soils with poor ion retention capacity [30]. Furthermore, $\mathrm{C}$ materials are resistant to toxic conditions and corrosive environments such as basic and acidic conditions because of their unique structure and electrical conductivity [31].

Van Laer et al. [32] reported that wood ash can be used as soil conditioner. Wood ash which is produced through combustion is not only alkaline, but it also contains high amounts of soluble macronutrients such as $\mathrm{Ca}, \mathrm{K}, \mathrm{P}$, and $\mathrm{Mg}$ [33]. Moreover, wood ash has the potential to reduce nutrient loss from crop harvesting and it is ideal for acid soils that are highly weathered because of its acid neutralising capacity. Base saturation and microbial activities increase with decreasing soil acidity [34]. However, with time, the effects of wood ash as a soil amendment reduces because of the biogeochemical interactions between amendment and soil profile $[35,36]$. The adsorption properties of wood ash are 
influenced by its specific surface area. Apart from its specific surface area, particle size distribution, pore size and pore volume are important physical properties that influence the use and quality of $C$ residues or ashes as an adsorbent [37]. Furthermore, the use of wood ash can increase water holding capacity, moisture content, and nutrient availability because its hydrophilic property enables it to retain water [38]. However, understanding the sorption mechanisms derived from literature is difficult because charcoal and wood ash as adsorbents vary depending on the raw materials used in their production. Therefore, the goal of this review is to provide the recent research findings and theory development on the role of charcoal and wood ash in agriculture. The specific objectives of this work are to discuss the: (1) effects of charcoal and wood ash on the sorption behaviour of inorganic $\mathrm{N}$, and (2) mechanisms that can be used to improve $\mathrm{N}$ availability by charcoal and wood ash In summary, this review focuses on how charcoal and wood ash improve $\mathrm{N}$ availability through physical, chemical and biological processes in acidic mineral soils.

\section{Acidic Soils of Malaysia}

Soils in the humic tropics (especially those under high temperature and rainfall throughout the year) are highly weathered because they exist in tropical environment, causing accumulation of sesquioxides and leaching of plant nutrients [39]. For example, approximately $72 \%$ of the land in Malaysia are Ultisols and Oxisols with goethite, kaolinite, gibbsite, and hematite in the clay fraction [40]. Lack of essential nutrients, mineral toxicities, and reduced water uptake are constraints to production in acid soils with preliminary visual symptoms of reduced root length on plant growth [41]. Naturally, because these types of soil lack available $\mathrm{P}, \mathrm{Ca}^{2+}$, and $\mathrm{Mg}^{2+}$, their productivity is low. Furthermore, nutrient availability is closely related to soil $\mathrm{pH}$. Low $\mathrm{pH}$ affects availability of macronutrients to cause their deficiencies. In most cases, $\mathrm{Al}^{3+}, \mathrm{Mn}^{2+}$ and $\mathrm{H}^{+}$toxicities and nutrient deficiencies limit the productivity of acidic soils. Low mineral content and rapid mineralisation of organic soil materials are constraints on sustainable tropical agriculture [13,42]. Application of acidic $\mathrm{N}$ fertilisers, $\mathrm{N}$ transformation such as nitrification that produces $\mathrm{H}^{+}$ ions and other reactions of releasing $\mathrm{H}^{+}$ions into the soil contribute to soil acidification [43]. Commonly, this problem is overcome by using a liming material such as ground magnesium limestone [44] because liming increases soil $\mathrm{pH}, \mathrm{Ca}^{2+}$ and $\mathrm{Mg}^{2+}$, base saturation, soil available nutrient, organic matter, and microbial activity. However, a liming material such as limestone is limited and expensive. Additionally, because tropical soils are low organic matter, improving their fertility, alternative soil amendments from agricultural wastes such charcoal and bark ash can be used because these wastes are abundant and readily available. In the tropics, organic amendments are used to restore soil fertility, particularly Ultisols and Oxisols by improving their chemical properties and nutrient bioavailability $[45,46]$.

\section{Soil Acidification}

Soil acidification poses a major challenge to agricultural sustainability [6]. This problem is particularly serious in highly weathered soils whose supply of most plant nutrients apart from $\mathrm{Fe}, \mathrm{Al}$, and $\mathrm{Mn}$ ions decrease with decreasing $\mathrm{pH}$. For example, as base cations such as $\mathrm{K}, \mathrm{Ca}, \mathrm{Mg}$, and $\mathrm{Na}$ acquire leached from highly weathered soils, these nutrients including $\mathrm{NH}_{4}{ }^{+}$and $\mathrm{NO}_{3}{ }^{-}$ions are replaced with $\mathrm{Fe}, \mathrm{Al}$, and $\mathrm{Mn}$. Hydrogen ions derived from $\mathrm{N}$ fertilisers such as urea particularly $\mathrm{NH}_{4}$ ions as a source of $\mathrm{N}$ release two $\mathrm{H}^{+}$ions for each conversion of $\mathrm{NH}_{4}{ }^{+}$ions to $\mathrm{NO}_{3}{ }^{-}$[47]. In addition to losing soil organic matter, Fe and $\mathrm{Al}$ hydrolysis which lead to further soil acidification, the fertility of Ultisols and Oxisols are decrease with time. During the decomposition of soil organic matter (depending on the organic matter derived), the organic acids produced affect soil acidity. If the decomposed plant does not have sufficient bases to fulfil microbial needs, the decomposition of plant debris will not only produce carbon dioxide, but it will also remove essential bases such as $\mathrm{Ca}^{2+}$ and $\mathrm{Mg}^{2+}$ from the soil [47]. 


\section{Forms of Nitrogen in Soil-Plant Systems}

Approximately $90 \%$ of the soil total $\mathrm{N}$ is composed of organic $\mathrm{N}$ which plays an essential role in $\mathrm{N}$ transformation and retention [7] and $90 \%$ of the $\mathrm{N}$ fertilisers in the world is in the inorganic form of $\mathrm{NH}_{4}{ }^{+}$. The $\mathrm{NH}_{4}$ ions are transformed into highly mobile $\mathrm{NO}_{3}{ }^{-}$ and $\mathrm{NO}^{2-}$ by nitrifying bacteria under aerobic conditions in soils [8]. Nitrite and $\mathrm{N}_{2} \mathrm{O}$ are present in small quantities in soils. Commonly, $\mathrm{N}$ is considered available if it can be taken by plants. The uptake of $\mathrm{N}$ from soils by plant roots is mainly in the forms of $\mathrm{NH}_{4}{ }^{+}$and $\mathrm{NO}_{3}{ }^{-}$ because organic $\mathrm{N}$ is mostly unavailable for direct plant uptake. Soil properties including $\mathrm{pH}$, texture, moisture and microbial activities influence $\mathrm{N}$ availability which commonly fluctuates significantly in both time and space [48]. At any given time, approximately $95 \%$ of the potentially available $\mathrm{N}$ in the soil is in organic form whether in plant and animal residue, bounded with organic matter, small animals or microorganisms [49]. This conversion is carried out by microorganisms as they decompose soil organic matter or residue from forest litter, previously grown crops and pastures. During decomposition, $\mathrm{N}$ can be immobilised from plant-available forms or mineralised into plant-available forms. The mineralisation rate depends on environmental factors such as temperature, moisture content, type or amount of organic $\mathrm{N}$ present. The ratio of $\mathrm{C}$ to $\mathrm{N}$ in residues is a deciding factor as to whether $\mathrm{N}$ is released or removed in the soil [50]. Soil $\mathrm{N}$ fractions are divided into inorganic and organic $\mathrm{N}$ fractions.

\section{Nitrogen Fractions and Pools in Soils}

Nitrogen often transforms in different forms [51]. The major forms of $\mathrm{N}$ include $\mathrm{N}$ source from organic matter, which is organic $\mathrm{N}$ and inorganic sources of $\mathrm{N}$ such as $\mathrm{NH}_{3}$, $\mathrm{NH}_{4}{ }^{+}, \mathrm{NO}_{3}{ }^{-}$and $\mathrm{N}_{2}$ gas. According to Brady and Weil [52], an atom of $\mathrm{N}$ can appear in different chemical forms each with its own properties, behaviour and significance for the environment. Korhonen et al. [53] opined that, despite the large pool of total N, mineral $\mathrm{N}$ concentrations are usually low compared with the ecosystem productivity and plant uptake which are limited by the availability of $\mathrm{N}$ indicates that the organic $\mathrm{N}$ availability is poor for plants and microorganisms.

Labile soil $\mathrm{N}$ fractions that transform rapidly during crop growing season are indicated by microbial biomass $\mathrm{N}$, a measure of $\mathrm{N}$ immobilisation and potential $\mathrm{N}$ mineralisation [54]. A measure of $\mathrm{N}$ storage in coarse organic matter known as particulate organic $\mathrm{N}$ is an intermediate fraction between slow and labile fractions which is also transformed rapidly during growing season [55]. This intermediate fraction is an essential substrate for soil microorganisms [55]. The available $\mathrm{N}$ fraction is the soil mineral $\mathrm{N}$ such $\mathrm{NO}_{3}{ }^{-}$and $\mathrm{NH}_{4}{ }^{+}$, either taken up by plants or lost to the environment [56,57]. The origin and importance of $\mathrm{N}$ fractions in the soil $\mathrm{N}$ cycling is replete in the literature [58-60]. Nonetheless, whether organic $\mathrm{N}$ fractions such as microbial biomass $\mathrm{N}$ and soil organic $\mathrm{N}$, and inorganic $\mathrm{N}$ exhibit synchronous patterns during $\mathrm{N}$ transformation in soils and how this process is affected remain uncertain [7].

\section{Soil Organic Nitrogen}

Schulten and Schnitzer [61] stated that organic form of $\mathrm{N}$ is a dominant component of soil N. Organic N fractions consist of acid-insoluble and acid-hydrolysable. Amino acids, amino sugar, ammonium and other unknown $\mathrm{N}$ sub-fractions are acid hydrolysable components [7]. Schulten et al. [62] revealed that most soil organic $\mathrm{N}$ is proteinaceous material or heterocyclic including purines and pyrimidines. Soil organic $\mathrm{N}$ primarily occurs as biogenic polymers that varies in decomposition state. The main building block of protein is the $\alpha$-amino acids, which makes up $50 \%$ of microbial biomass [63], and major component of soil organic N [64]. Moreover, amides consist of $\alpha$ amino-N, peptides contain less abundant non- $\alpha$ amino-N moieties. Amino sugar is the second most abundant component of soil organic $\mathrm{N}$, the principal of microbial cell walls $\mathrm{N}$-containing components $[64,65]$. Chitin is the main amino sugar polymer in fungal cell walls, whereas bacterial cell walls have a peptidoglycan layer composed from $\alpha$-amino acid and bacterial amino sugar. Shmidt et al. [66] reported that decomposition of soil organic matter or soil organic $\mathrm{N}$ 
is regulated by several processes and factors such as molecular structure, condensation reaction, rhizosphere input, soil depth, freezing-thawing, residues and microbial products. On the whole, multiple processes which preserve and release $\mathrm{N}$ from soil organic matter significantly affect soil $\mathrm{C}$ and $\mathrm{N}$ cycling.

Primarily, organic $\mathrm{N}$ is in the form of urea and amino acids, along with proteins and peptides [67]. Fulvic and humic substances also contribute to the pool of dissolved organic N. However, proteins and peptides in the soil are decomposed by protease secreted by soil microorganisms into their constituent amino acids units [67]. Organic $\mathrm{N}$ form in soils is divided into two categories: (i) organic residues including partial decomposition product and un-decayed plant and animal residues, and (ii) soil organic matter and humus. The humus consists of humic substances that are high in molecular weight. They are partly aromatic substances formed by secondary reaction, amorphous and non-humic such as chemically recognisable substances (nucleic acids, amino acids and carbohydrate) [58]. Throughout the decomposition of organic matter by soil microorganisms, excess $\mathrm{N}$ is transformed to $\mathrm{NO}_{3}{ }^{-}$and $\mathrm{NH}_{4}{ }^{+}$. When organic matter is rich in $\mathrm{N}$, mineralisation occurs. Ashton et al. [68] reported that, when organic $\mathrm{N}$ undergoes mineralisation to inorganic $\mathrm{N}$, it is taken up by plants easily. Mineralisation is a process when microorganisms convert organic $\mathrm{N}$ to inorganic forms. However, degradation of organic matter with low $\mathrm{N}$ content causes immobilise $\mathrm{NH}_{4}{ }^{+}$and $\mathrm{NO}_{3}{ }^{-}$because degrading microorganisms scavenge available $\mathrm{N}$ from soil systems [69]. Vigil and Kissel [70] reported that degradation of organic materials with a C:N ratio more than $40: 1$ immobilises $\mathrm{N}$, whereas decomposition lower than this ratio mineralises $\mathrm{N}$. Thus, the rate of organic $\mathrm{N}$ mineralisation is an essential factor controlling ecosystem productivity [71]. According to Walworth [69], mineralisation can be divided into ammonification (Equation (1)) and hydrolysis (Equation (2)), where organic $\mathrm{N}$ is converted to $\mathrm{NH}_{3}$ and the conversion in water of $\mathrm{NH}_{3}$ to $\mathrm{NH}_{4}{ }^{+}$.

Ammonification:

$$
\mathrm{R}-\mathrm{NH}_{2}+\mathrm{H}_{2} \mathrm{O} \rightarrow \mathrm{NH}_{3}+\mathrm{R}-\mathrm{OH}+\text { energy }
$$

Ammonia hydrolysis:

$$
\mathrm{NH}_{3}+\mathrm{H}_{2} \mathrm{O} \rightarrow \mathrm{NH}_{4}^{+}+\mathrm{OH}
$$

\section{Soil Inorganic Nitrogen}

Hawkins and Robbins [72] described that, $\mathrm{NH}_{4}{ }^{+}$and $\mathrm{NO}_{3}{ }^{-}$are prevalent inorganic forms of $\mathrm{N}$ which are commonly taken up by plants. The major form of inorganic $\mathrm{N}$ in aerobic soils is $\mathrm{NO}_{3}{ }^{-}$whereas $\mathrm{NH}_{4}{ }^{+}$is the major form in acidic soils or flooded wetland [73].

\section{Soil Inorganic Nitrogen (Nitrate-Nitrogen)}

Nitrate is a negatively-charged ion, thus it is difficult for $\mathrm{NO}_{3}{ }^{-}$to form surface complexes with soil particles. Nitrate salts are mobile with soil water, highly soluble and prone to leaching if not utilised by microorganisms or taken up by plants [52,74]. According to Walworth [69], denitrification reduces $\mathrm{NO}_{3}{ }^{-}$to $\mathrm{N}_{2} \mathrm{O}$ or dinitrogen gas $\left(\mathrm{N}_{2}\right)$ by anaerobic bacteria (Equation (3)):

$$
2 \mathrm{HNO}_{3} \rightarrow 2 \mathrm{HNO}_{2} \rightarrow 2 \mathrm{NO} \rightarrow \mathrm{N}_{2} \mathrm{O} \rightarrow \mathrm{N}_{2}
$$

Furthermore, this reaction is the primary mechanism for $\mathrm{N}$ loss when soils are saturated with rain, waterlogged condition or poorly aerated soils. Organic matter provides energy and $\mathrm{C}$ for denitrifying bacteria through oxidation and $\mathrm{NO}_{3}{ }^{-}$acts as the terminal electron acceptor [69].

\section{Soil Inorganic Nitrogen (Ammonium-Nitrogen)}

Ammonium is the predominant source of $\mathrm{N}$ that is available for plant nutrition although the average of $\mathrm{NH}_{4}{ }^{+}$concentration of soils is often lower than $\mathrm{NO}_{3}{ }^{-}$[75]. However, when plants are grown in soils with high amount of $\mathrm{NH}_{4}{ }^{+}$in the absence of $\mathrm{NO}_{3}{ }^{-}$, toxicity symptoms occur except rice, onion, leek, blueberry and cranberry which prefer $\mathrm{NH}_{4}{ }^{+}$[76]. 
In addition, $\mathrm{NH}_{4}{ }^{+}$ion in neutral to acidic water, and under high $\mathrm{pH}$, it is converted to $\mathrm{NH}_{3}$. At $\mathrm{pH}$ 9, approximately half of the $\mathrm{NH}_{3}$ is in gaseous and less than $10 \%$ of it is in gaseous form below $\mathrm{pH} 8$ [77]. Ammonium is attracted to the negatively charge soil particles because of its positive charge, thus it is held as exchangeable cation in soils and it does not leach easily. Moreover, $\mathrm{NH}_{4}{ }^{+}$can be trapped between the layers of clay minerals that exhibit swelling and shrinking through $\mathrm{NH}_{4}^{+}$fixation [52,69].

The $\mathrm{NH}_{4}{ }^{+}$is rapidly oxidised to $\mathrm{NO}_{3}{ }^{-}$under sufficient oxygen condition through nitrification because it is relatively unstable in aerobic soils. During nitrification, the conversion of $\mathrm{NH}_{4}{ }^{+}$takes place in two steps and they are the conversion of $\mathrm{NH}_{4}{ }^{+}$into $\mathrm{NO}_{2}{ }^{-}$by Nitrosomonas (oxidising bacteria) (Equation (4)), and the oxidation of $\mathrm{NO}_{2}{ }^{-}$to $\mathrm{NO}_{3}{ }^{-}$by Nitrobacter (Equation (5)).

First step of nitrification:

$$
2 \mathrm{NH}_{4}^{+}+3 \mathrm{O}_{2} \rightarrow 2 \mathrm{NO}_{2}^{-}+2 \mathrm{H}_{2} \mathrm{O}+4 \mathrm{H}^{+}
$$

Second step of nitrification:

$$
2 \mathrm{NO}_{2}{ }^{-}+\mathrm{O}_{2} \rightarrow 2 \mathrm{NO}_{3}{ }^{-}
$$

As demonstrated by Walworth [69], nitrification causes soil acidity through production of large amount of $\mathrm{H}^{+}$ions and oxidation of $\mathrm{NO}_{2}{ }^{-}$, and because this reaction occurs rapidly, $\mathrm{NO}_{2}{ }^{-}$rarely forms inorganic soil $\mathrm{N}$.

\section{Nitrogen as a Fertiliser}

Because $\mathrm{N}$ forms are easily converted in soils, the choice of $\mathrm{N}$ fertiliser is based on cost [69]. Nitrogen fertilisers are classified as organic or chemical, the latter being highly soluble when applied to soils [78]. The use of synthetic $\mathrm{N}$ fertilisers has reduced major elemental constraints to supply organic $\mathrm{C}$ and $\mathrm{N}$ originally managed by organic manure amendments, leguminous culture and uncultivated periods [79]. The common fertilisers are listed in Table 1 Urea is the most used solid $\mathrm{N}$ fertiliser because it can be easily handled, stored, transported, and produced [80].

Table 1. Some commonly used nitrogen fertilizers [69].

\begin{tabular}{ccc}
\hline Fertiliser & \% Nitrogen & Composition \\
\hline Ammonium sulfate & 20.5 & $\left(\mathrm{NH}_{4}\right)_{2} \mathrm{SO}_{4}$ \\
Calcium nitrate & 16 & $\mathrm{Ca}\left(\mathrm{NO}_{3}\right)_{2}$ \\
Urea & 45 & $\left(\mathrm{NH}_{2}\right)_{2} \mathrm{CO}$ \\
Anhydrous ammonia & 82 & $\mathrm{NH}_{3}$ \\
Diammonium phosphate & 20 & $\left(\mathrm{NH}_{4}\right)_{2} \mathrm{HPO}_{4}$ \\
Ammonium polyphosphate & $10-15$ & $\left(\mathrm{NH}_{4} \mathrm{PO}_{3}\right)_{\mathrm{n}}$ \\
Urea ammonium nitrate & $28-32$ & $\left(\mathrm{NH}_{2}\right)_{2} \mathrm{CO}, \mathrm{NH}_{4} \mathrm{NO}_{3}$ \\
\hline
\end{tabular}

\section{Urea}

Urea, the world's most common solid $\mathrm{N}$ fertiliser is a white crystalline organic chemical, and it is also known as carbamide $\left(\mathrm{NH}_{2} \mathrm{CONH}_{2}\right)$. Among the other solid sources of $\mathrm{N}$ available in the market, urea has the highest $\mathrm{N}$ content $(46 \% \mathrm{~N})$. Synthetic urea is manufactured from $\mathrm{NH}_{3}$ and carbon dioxide under high pressure and moderate temperature with the help of suitable catalyst [78,81].

$$
2 \mathrm{NH}_{3}+\mathrm{CO}_{2} \rightarrow \mathrm{NH}_{2} \mathrm{COONH}_{4}
$$

Ammonium carbamate which is produced is relatively an unstable intermediate, and with time decomposed urea is recovered. Thereafter, $99 \%$ concentrated urea solution is sprayed into a chamber where urea crystals are formed [78].

$$
\mathrm{NH}_{2} \mathrm{COONH}_{4} \rightarrow \mathrm{NH}_{2} \mathrm{CONH}_{2}+\mathrm{H}_{2} \mathrm{O}
$$


The $\mathrm{NH}_{3}$ needed for urea manufacturing is made by combining one mole of $\mathrm{N}$ with three moles of hydrogen with iron oxide $\left(\mathrm{Fe}_{3} \mathrm{O}_{4}, \mathrm{FeO}\right)$ as a catalyst. In addition, urea is a simple organic $\mathrm{N}$ salt which is highly soluble, but it must be hydrolysed by enzyme called urease to form $\mathrm{NH}_{4}{ }^{+}$before it is utilised (Equation (8)). If urea or ammonium fertilisers are used at $\mathrm{pH} 8$ or above, $\mathrm{NH}_{3}$ volatilisation causes loss of $\mathrm{N}$ especially if the fertiliser is not incorporated into the soil immediately after utilisation to prevent loss. During urea hydrolysis, soil pH increases rapidly and substantial $\mathrm{N}$ is lost through volatilisation even in medium pH soils [69].

Urea hydrolysis:

$$
\mathrm{CO}\left(\mathrm{NH}_{2}\right)_{2}+3 \mathrm{H}_{2} \mathrm{O} \rightarrow 2 \mathrm{NH}_{3}+\mathrm{CO}_{2}+2 \mathrm{H}_{2} \mathrm{O} \rightarrow 2 \mathrm{NH}_{4}{ }^{+}+\mathrm{CO}_{2}+2 \mathrm{OH}^{-}
$$

Currently, a significant amount of urea fertilisers are applied onto agricultural land resulting in soil acidity, leaching of $\mathrm{NO}_{3}{ }^{-}$and environmental pollution such as eutrophication [82].

\section{Role of Nitrogen in Crops Productivity}

Kusano et al. [83] described $\mathrm{N}$ as one of the most essential nutrients for biomass production and plant growth that is involved in the synthesis of nucleic acids, amino acids, lipids, chlorophyll and various N-containing metabolites. Nitrogen is one of the most widely used nutrients, because plants need $\mathrm{N}$ in the largest quantity compared with other mineral elements such as P and K [84]. Nitrogen deficiency is a limiting element for plant growth and development [85-88] including root architecture [89], leaf development [90], flowering [91], and seed dormancy [92].

\section{Nitrogen Availability in Soils}

Nitrogen is considered available if it is vulnerable to plants uptake. However, there is no sufficient information about the quantitative measurements of available $\mathrm{N}$ or $\mathrm{N}$ availability and the terms of available $\mathrm{N}$ and $\mathrm{N}$ availability in definition [93]. Nitrogen in a chemical form that can be readily absorbed by plant roots is called available $\mathrm{N}$. In another words, available $\mathrm{N}$ is the $\mathrm{N}$ that is present within the root zone of plants [94]. The processes that contribute to available $\mathrm{N}$ supply in soils are organic matter, addition of fertilisers, symbiotic fixation, non-symbiotic fixation and rainfall. Nitrate and exchangeable $\mathrm{NH}_{4}{ }^{+}$in a rooting depth of a crop are directly available to plant roots in arable soils. In the tropics, management of $\mathrm{N}$ is essential because providing much of this element can become unavailable [95].

\section{Factors Affecting Nitrogen Availability to Crops}

Soil drainage, texture, and slope steepness affect $\mathrm{N}$ transport and transformation, utmost accessibility thus leading to losses. Moreover, soil aeration, electrical conductivity, rainfall, temperature and moisture affect the rate of $\mathrm{N}$ mineralisation and nitrification affecting osmotic potential and altering substrate availability from decomposition of organic matter [96], nutrient cycling and $\mathrm{N}$ losses through denitrification, leaching and surface runoff. Decomposition of organic matter releases $\mathrm{N}$ rapidly in well aerated soil, and humid climate because soil climatic conditions affect biomass and microbial activities [97]. Abera et al. [98] stated that vegetation also affects nitrification and mineralisation through the amount and quality of litter. Soil moisture is the most crucial factor that limits microbial activities because in the tropics, temperature is not a limiting factor. Maximising $\mathrm{N}$ accessibility from autochthonous soil $\mathrm{N}$ and supplemental $\mathrm{N}$ from manures, fertilisers or compost to optimise yield is the initial requirement for understanding $\mathrm{N}$ availability [69].

\section{Nitrogen Transformation in Soil-Crops Systems}

Anthropogenic activities such as rapid industrial development and intensive agricultural production with a substantial amount of $\mathrm{N}$ fertilisation cause losses of $\mathrm{C}$ and $\mathrm{N}$ to the environment [3]. Nitrogen fertilisers are highly mobile in soils and because of this, they should be carefully used in agriculture to prevent losses through volatilisation, denitrification, and leaching in particular [4]. Apart from poor synchrony of fertiliser 
nutrient release for timely uptake by plants, the problem of inefficiency of these fertilisers is compounded in highly weathered acid soils which are low nutrients and rapid mineralisation of soil organic matter because of high rainfall and temperature [5]. Nitrogen losses from agricultural systems via denitrification, volatilisation and leaching have negatively impacted the atmosphere, surface and ground water, and uncultivated ecosystem. Approximately $90 \%$ of the soil total $\mathrm{N}$ is composed of organic $\mathrm{N}$ which plays an important role in $\mathrm{N}$ transformation and retention [7]. If the $\mathrm{N}$ applied is not taken up by plants or immobilised in soil organic $\mathrm{N}$ pool, it is prone to losses from emissions of $\mathrm{N}_{2} \mathrm{O}$ and $\mathrm{NO}$ following nitrification-denitrification process, leaching of $\mathrm{NO}_{3}{ }^{-}$, volatilisation of $\mathrm{NH}_{3}$, all of which can have a range of undesirable on-site and off-site environmental outcomes [99]. Understanding $\mathrm{N}$ transformations and soil microbes is important for understanding and managing ecosystem health and productivity. Nitrogen takes nine forms in soils equivalent to different oxidative state in (Table 2) [100].

Table 2. Main Forms of Nitrogen in soils and their Oxidation State.

\begin{tabular}{ccc}
\hline Name & Chemical Formula & Oxidation State \\
\hline Nitrate & $\mathrm{NO}_{3}-$ & +5 \\
Nitrogen dioxide [g] & $\mathrm{NO}_{2}$ & +4 \\
Nitrite & $\mathrm{NO}_{2}$ & +3 \\
Nitric oxide [g] & $\mathrm{NO}$ & +2 \\
Nitrous oxides [g] & $\mathrm{N}_{2} \mathrm{O}$ & 0 \\
Dinitrogen [g] & $\mathrm{N}_{2}$ & -3 \\
Ammonia [g] & $\mathrm{NH}_{3}$ & -3 \\
Ammonium & $\mathrm{NH}_{4}{ }^{+}$ & -3 \\
Organic N & $\mathrm{R}_{\mathrm{NH} 3}$ & \\
\hline
\end{tabular}

Gases (g) occur both free in the soil atmosphere and dissolved in soil water.

\section{Mineralisation and Immobilisation}

In older literature, mineralisation is known as ammonification because $\mathrm{NH}_{4}{ }^{+}$is viewed as immediate product of mineralisation. According to Myrold et al. [101], mineralisation is the production of inorganic $\mathrm{N}$ from organic $\mathrm{N}$ whereas immobilisation is the assimilation of inorganic $\mathrm{N}$ into organic forms. Globally, soil $\mathrm{N}$ mineralisation rates are believed to be controlled by climate and soil properties [102]. Mineralisation is suppressed by soil acidification [102]. However, addition of organic matter and soil substrate increase $\mathrm{N}$ mineralisation $[103,104]$. Soil fauna such as several microorganisms including fungi, aerobes and anaerobes bacteria play an essential role in these processes. They are responsible for decomposition of wastes, for microorganisms to populate, indirectly creating a suitable environment for micro-fauna such as earthworm, and termites. These two processes are fundamental because a by-product of all heterotrophic soil organisms consume organic materials for C and energy [100]. Mineralisation and immobilisation occur simultaneously within the small volume of soils; thus, it is important to differentiate these two processes. Moreover, mineralisation results in increasing inorganic $\mathrm{N}$, whereas immobilisation decreases N. It is important to make a distinction between gross and net mineralisation and immobilisation as a result of the simultaneous nature of these processes. Furthermore, the total amount of soluble $\mathrm{N}$ produced by microorganisms is gross $\mathrm{N}$ mineralisation, whereas the total amount of soluble $\mathrm{N}$ consumed is gross $\mathrm{N}$ immobilisation. Net mineralisation is when gross mineralisation exceeds gross immobilisation resulting in inorganic $\mathrm{N}$ availability. On the other hand, net immobilisation is when gross immobilisation exceeds gross mineralisation resulting in decreasing amount of inorganic N [100]. According to Follet [49], mineralisation is when $\mathrm{NH}_{4}{ }^{+}$is released. In sufficient oxygen, microorganisms in the soil convert $\mathrm{NH}_{4}{ }^{+}$ions to $\mathrm{NO}_{3}{ }^{-}$ions with $\mathrm{NO}_{2}$ as an intermediate form (nitrification). Addition of charcoal and wood ash as amendments affect the $\mathrm{C}: \mathrm{N}$ ratio and generally immobilisation of $\mathrm{N}$ occurs when the C: $\mathrm{N}$ ratio increases [105]. 


\section{Nitrification}

Nitrification is a process when $\mathrm{NH}_{4}{ }^{+}$is converted to $\mathrm{NO}_{3}{ }^{-}[49,106]$. Thus, nitrification is the microbial oxidation process of reducing $\mathrm{N}$ to $\mathrm{NO}_{3}{ }^{-}$ions and $\mathrm{NO}_{2}{ }^{-}$ions [100], carried out by two different groups of microorganisms specifically autotrophic and heterotrophic nitrifiers, and is crucial and useful parameter of the soil environment [107]. In most ecosystems, $\mathrm{NO}_{3}{ }^{-}$is formed in situ through nitrification, although some $\mathrm{NO}_{3}{ }^{-}$is supplied as fertilisers or acid rain. Nitrate is more mobile than $\mathrm{NH}_{4}{ }^{+}$because of its negative charge, and the ionised source of $\mathrm{NH}_{3}$ in soil water is demonstrated in Equation (9) [100]:

$$
\mathrm{NH}_{4}{ }^{+}(\mathrm{aq}) \rightarrow \mathrm{NH}_{3}(\mathrm{aq})+\mathrm{H}^{+}(\mathrm{aq})
$$

Ammonium ions are held on cation exchange sites associated with clay surfaces, organic matter and variable-charge mineral because of their positive charge, whereas $\mathrm{NO}_{3}{ }^{-}$is transported out of roots zone when precipitation exceeds evapotranspiration and also, they are prone to denitrification. Denitrifying bacteria transforms $\mathrm{NO}_{3}{ }^{-}$to $\mathrm{N}$ gas [100]. In a short-term field experiment, Berg and Roswall [108] demonstrated that nitrification potential, clay mineral content and amount of $\mathrm{NH}_{4}{ }^{+}$oxidisers increased with increasing soil moisture. Macura and Stotzky [109] adds that after the addition of montmorillonite, nitrification rate was higher. In many soils, nitrification is the major source of acidity, including hydrologic loss of base cations as $\mathrm{H}^{+}$displace other cations from exchange sites including mostly in highly weathered tropical soils. Moreover, soil acidity affects soil CEC [100]. Application of amendments such as charcoal, wood ash and biochar promote net nitrification particularly in natural environment because of their liming effect or removal of inhibiting compounds such as polyphenols or tannins $[110,111]$; although application of amendments such as charcoal, biochar and wood ash may have no significant effect on gross or net nitrification rates in agricultural soils [110,112].

\section{Denitrification}

Denitrification is conversion of soil $\mathrm{NO}_{3}{ }^{-}$to $\mathrm{N}$ gases such as $\mathrm{NO}, \mathrm{N}_{2} \mathrm{O}$ and $\mathrm{N}_{2}$ [100]. In another study, Follet [49] stated that $\mathrm{NO}_{2}{ }^{-}$does not accumulate in soils because it is rapidly denitrified to $\mathrm{NO}, \mathrm{N}_{2} \mathrm{O}$ and $\mathrm{N}_{2}$. Additionally, denitrification causes $\mathrm{NO}_{3}{ }^{-}$loss to the atmosphere. In addition, Dobrovol'skaya et al. [107] reported that formation of $\mathrm{N}_{2} \mathrm{O}$ is common in soils that are structureless, salinised, $\mathrm{pH}$ lower than 7 , contaminated with pesticides and high in heavy metals. Mostly, heterotrophic bacteria can denitrify $\mathrm{N}$ because they use $\mathrm{NO}_{3}{ }^{-}$as a terminal electron acceptor during respiration instead of oxygen, and most denitrifiers undertake denitrification only when there is sufficient oxygen because $\mathrm{NO}_{3}{ }^{-}$is a less efficient electron acceptor than oxygen. In waterlogged condition, diffusion of oxygen to microsites reduces significantly [100]. Some of the conditions required for denitrification to occur are: (i) presence of bacteria possessing the metabolic capacity, (ii) suitable reductants (organic carbon), (iii) absence or restriction of oxygen and (iv) $\mathrm{N}$ oxides availability $\left(\mathrm{NO}, \mathrm{N}_{2} \mathrm{O}\right.$ or $\mathrm{N}_{2}$ ) (Table 3) [113-115].

Table 3. Factors affecting the proportion of $\mathrm{N}_{2} \mathrm{O}$ and $\mathrm{N}_{2}$ produced during denitrification [48].

\begin{tabular}{cc}
\hline Factor & Will Increase $\mathbf{~}_{\mathbf{2}} \mathbf{O}$ or $\mathbf{N}_{\mathbf{2}}$ \\
\hline $\mathrm{NO}_{3}{ }^{-}$or $\mathrm{NO}_{2}{ }^{-}$ & Increasing oxidant \\
Oxygen & Increasing oxygen \\
Carbon & Decreasing C availability \\
$\mathrm{pH}$ & Decreasing $\mathrm{pH}$ \\
$\mathrm{H}_{2} \mathrm{~S}$ & Increasing Sulfide \\
Temperature & Decreasing temperature \\
Enzyme status & Low $\mathrm{N}_{2} \mathrm{O}$ reductase activity \\
\hline
\end{tabular}

However, the end product and the rate of the $\mathrm{N}_{2} \mathrm{O}$ producing processes are influenced by conditions and properties of the soil such as organic matter, N, substrate availability and form, $\mathrm{pH}$ and oxidative conditions [116]. 


\section{Volatilisation}

Volatilisation can occur from surface-applied $\mathrm{N}$ sources. Nitrogen loss as $\mathrm{NH}_{3}$ gas. Liu et al. [117] reported that, $\mathrm{NH}_{3}$ volatilisation is the main $\mathrm{N}$ gas loss pathway and approximately $64 \% \mathrm{~N}$ applied is lost through volatilisation. Ammonia loss occurs when $\mathrm{N}$ based fertilisers are used. Ammonia is an intermediate form of $\mathrm{N}$ during the process in which urea is transformed to $\mathrm{NH}_{4}{ }^{+}-\mathrm{N}$. Ammonium ions in the soil solution enter into an equilibrium reaction with $\mathrm{NH}_{3}$ in the soil solution, whereas significant amount of $\mathrm{NH}_{3}$ volatilised into the atmosphere can cause air pollution. In addition, $\mathrm{N}$ deposition can cause eutrophication thus, destroying biodiversity $[118,119]$. The important factors that contribute to $\mathrm{N}$ losses via $\mathrm{NH}_{3}$ volatilisation include the activity of enzyme urease, assimilation of ammonia by soil biota, buffering capacity, soil physical properties that control mass flow and diffusion of water and dissolved solutes, and soil $\mathrm{pH}$ [120]. Rochette et al. [121] reported that with the equilibrium relationships during experiment between $\mathrm{pH}, \mathrm{NH}_{3}$ and $\mathrm{NH}_{4}{ }^{+}$as $\mathrm{pH}$ is increased by urea hydrolysis, the activity of $\mathrm{H}^{+}$required to transform $\mathrm{NH}_{3}$ to $\mathrm{NH}_{4}{ }^{+}$decreased thus and the proportion of $\mathrm{NH}_{3}$ release to the air relative to the proportion converted to $\mathrm{NH}_{4}{ }^{+}$increased with increasing urea application (Equation (12)). A study in Nebraska found that when urea-based fertilisers are left on the soil surface, the risk of $\mathrm{NH}_{3}$ volatilisation increased on poorly buffered, coarse textured soils without rainfall to move $\mathrm{N}$ seep into soils and when heavy rainfall occurred, the risk of $\mathrm{NH}_{3}$ volatilisation decreased. However, leaching can occur in these conditions [122]. Stevenson [123] summarised that $\mathrm{NH}_{3}$ volatilisation is most significant when $\mathrm{pH}$ is greater than 7 , and the loss is also greater in soils with low CEC. Ammonia loss can increase when organic wastes which are high in $\mathrm{pH}$ and $\mathrm{N}$ decompose on soil surface. Furthermore, $\mathrm{NH}_{3}$ volatilisation increases with increasing temperature, principally in alkaline and neutral soil as they become dry and losses are high from urea applied as urease hydrolyses urea to $\mathrm{NH}_{3}$ gas. Firstly, $\mathrm{NH}_{3}$ volatilisation involves urea hydrolysis through urease. Urease is an extra-cellular enzyme produced as by product of plant residues or several soil microorganisms [124].

Urea hydrolysis:

$$
\begin{gathered}
\left(\mathrm{NH}_{2}\right)_{2} \mathrm{CO}+2 \mathrm{H}_{2} \mathrm{O} \rightarrow\left(\mathrm{NH}_{4}\right)_{2} \mathrm{CO}_{3} \\
\left(\mathrm{NH}_{4}\right)_{2} \mathrm{CO}_{3}+2 \mathrm{H}^{+} \rightarrow 2 \mathrm{NH}_{4}^{+}+\mathrm{CO}_{2}+\mathrm{H}_{2} \mathrm{O} \\
\mathrm{NH}_{4}^{+}+\mathrm{OH}^{-} \rightarrow \mathrm{NH}_{3}+\mathrm{H}_{2} \mathrm{O}
\end{gathered}
$$

In most soils, $\mathrm{pH}$ increases to a range of 7 to 9 upon completion of the urea hydrolysis, because one mole of urea molecule utilises two moles of $\mathrm{H}^{+}$ions from soil water to produce two moles of $\mathrm{OH}^{-}$[124]. The increase in $\mathrm{pH}$ causes the proportion of $\mathrm{N}$ in the form of $\mathrm{NH}_{3}$ to increase and this increases the risk of $\mathrm{NH}_{3}$ volatilisation. The efficiency of surface applied urea for $\mathrm{N}$ crop uptake reduces because of volatilisation. However, it can be controlled by retarding hydrolysis using urease inhibitors or enhancing $\mathrm{NH}_{4}{ }^{+}$retention formed by urea hydrolysis using amendments with high specific surface area and CEC. This approach does not only enhance $\mathrm{NH}_{4}{ }^{+}$retention but it also improves soil buffering capacity to reduce in $\mathrm{pH}$ [125]. This strategy was adopted by Paiva et al. [126] to coat fertiliser granules with oxidised charcoal as a fertiliser amendment because during hydrolysis, $\mathrm{N}$ fertilisers such as urea must be in the microsite contact with the oxidised charcoal to maximise efficacy. This oxidation contributes to increase in CEC by increasing the contents of phenolic, carboxylic, $\mathrm{N}$-containing groups, thus, improving in the metal adsorption capacity of charcoal [127].

\section{Leaching}

Leaching is loss of soluble nitrate because it moves with soil water, commonly excess water below plant root zone through drainage systems. Nitrate that moves below plant root zone has the potential to enter groundwater of surface water because $\mathrm{NO}_{3}{ }^{-}$can be leached from any soil if rainfall or irrigation moves water through root zone. According to GDRC [50], several chemical reactions change urea to $\mathrm{NH}_{4}{ }^{+}$to $\mathrm{NO}_{3}{ }^{-}$form leading to leaching of $\mathrm{NO}_{3}{ }^{-}$from the soil profile. Approximately $90 \%$ of the $\mathrm{N}$ fertilisers in the world 
are in the inorganic form $\mathrm{NH}_{4}{ }^{+}$. The ammonium ions are transformed into highly mobile $\mathrm{NO}_{3}{ }^{-}$and $\mathrm{NO}_{2}{ }^{-}$by nitrifying bacteria under aerobic conditions in soils [8]. Nitrogen leaching and runoff do not only reduce nutrient uptake efficiency, but they also cause serious environmental pollution such as eutrophication [8]. Nitrate ions are the primary form of $\mathrm{N}$ leached, soluble in soil water and moves freely through most soils [49]. Jury and Nielson [128] stated that the movement of $\mathrm{NO}_{3}{ }^{-}$is controlled by mass flow and diffusion within the soil solution. Di and Cameron [129] added that high amount of $\mathrm{NO}_{3}{ }^{-}$ leaching loss occurs when there is high amount of $\mathrm{NO}_{3}{ }^{-}$in the soil profile together with or followed by high drainage volume. Fertilisers, effluents and mineralisation of soil organic $\mathrm{N}$ could be some of the sources of $\mathrm{NO}_{3}{ }^{-}$[130]. It is well documented that rainfall, irrigation, tile drainage and water table fluctuation influence $\mathrm{NO}_{3}{ }^{-}$leaching rate [131]. In addition, fertilisation levels, type of fertiliser, time and method of application, type of plant, agronomic practices and soil properties such as soil $\mathrm{pH}$, soil texture and soil organic matter content influence leaching of $\mathrm{NO}_{3}{ }^{-}$.

\section{Crop Removal, Soil Erosion and Runoff}

Inorganic $\mathrm{N}$ can be lost from soil system by plant uptake. According to O'Leary et al. [132], plant removal such as harvesting reduces soil $\mathrm{N}$ loss. Foster et al. [133] opined that, soil erosion accelerates movement of $\mathrm{N}$ into surface water because soil erosion by water includes detachment, transport and deposition of soil particles whether through surface flow or raindrops. For example, some sediments may be transported long distance before being deposited or reaching a stream, lake or reservoir. This results in movement of $\mathrm{NH}_{4}{ }^{+}$because it is sorbed to the finer sediments or surface of clays. Meanwhile, $\mathrm{NO}_{3}{ }^{-}$is water soluble thus, it moves with water until it re-enters available soil pool, or being utilised by microorganisms, plants, denitrified or deposited to surface or ground water. Mostly, source of $\mathrm{N}$ that degrades surface water is that which is transported in soil organic matter [49]. The key factors that influence loss of dissolved $\mathrm{N}$ in runoff are soil properties and amount and timing of rainfall. Soil permeability and landscape affect infiltration rate. Soil organic matter, initial water content, soil texture and soil structure influence the amount of water infiltration [49]. Moreover, a combination of high rainfall and soil condition of high runoff potential accelerates surface runoff losses. Incomplete incorporation of surface-crop residues and higher dissolved $\mathrm{N}$ concentration in surface soil because of accumulation of residues and decomposition might be the reasons for high surface runoff. Lehman and Ahuja [134] added that when there is barrier such as Fragipan in the soil profile, high concentration of soluble $\mathrm{N}$ can occur resulting in return flow of leached $\mathrm{N}$ back to the soil surface.

\section{Nitrogen Use Efficiency}

Lassaletta et al. [135] reported that, the world Nitrogen Use Efficiency (NUE) on agricultural lands has declined by approximately $20 \%$. Nitrogen Use Efficiency has various definitions [136], such as the definition of Nielsen [137], that NUE indicates the relative balance between the amount of fertiliser taken up and used by crop versus the amount of fertiliser N lost. Another definition of NUE is yield per unit of N available in the soil [138]. In addition, NUE can be defined as crop yield per unit of nutrient applied [139]. According to Kant et al. [138], in the plant life cycle, there are two stages for $\mathrm{N}$ used. The first stage is during biomass formation when there is amount of $\mathrm{N}$ uptake, assimilation into amino acids and nitrogenous compounds and storage. The second stage is the amount of $\mathrm{N}$ partitioned to the seed, resulting in final yield. At the plant level, NUE is subjected to N uptake efficiency (NUpE) and N utilisation efficiency (NUtE) [73,79,140,141]. Xu et al. [73] defined $\mathrm{NUpE}$ as the capability of plant roots to take $\mathrm{N}$ from the soil and NUtE was defined as the fraction of plant-acquired $\mathrm{N}$ to be converted to total plant biomass or grain yield. Some NUE calculations take into account only nutrient inputs from fertilisers and nutrients from mineralisation of organic matter, manures and crop residues over several crop cycles [142]. However, it also depends on the form of $\mathrm{N}$ taken up and applied [79,141]. The amount of remaining mineral $\mathrm{N}$ after harvesting crops plays an important role in the environmental $\mathrm{N}$ pollution problem [143] because a high NUE does not suggest $\mathrm{N}$ surplus does not surpass 
critical environmental threshold. The three commonly used as NUE indicators are partial factor productivity for $\mathrm{N}$ fertiliser $\left(\mathrm{PFP}_{\mathrm{N}}, \mathrm{kg}\right.$ grain $\left.\mathrm{kg}^{-1} \mathrm{~N}_{\text {fert }}\right)$, apparent $\mathrm{N}$ use efficiency (ANUE, \%) and $\mathrm{N}$ recovery efficiency $\left(\mathrm{RE}_{\mathrm{N}}, \%\right)$. The ratio of crop yield per unit of mineral fertiliser $\mathrm{N}$ applied is the definition for $\mathrm{PFP}_{\mathrm{N}}[144,145]$ and it is calculated as:

$$
\mathrm{PFP}_{\mathrm{N}}=\mathrm{Y}_{\mathrm{g}} / \mathrm{N}_{\text {fert }}
$$

where, $\mathrm{Y}_{\mathrm{g}}=$ grain yield $\left(\mathrm{kg} \mathrm{ha}^{-1}\right), \mathrm{N}_{\text {fert }}=$ amount of $\mathrm{N}$ mineral fertiliser application rate $\left(\mathrm{kg} \mathrm{N} \mathrm{ha}^{-1}\right)$.

Al Naggar et al. [146], demonstrated ANUE formula as:

$$
\mathrm{ANUE}=\mathrm{N}_{\mathrm{g}} / \mathrm{N}_{\text {fert }}
$$

where, $\mathrm{N}_{\mathrm{g}}=$ quantity of $\mathrm{N}$ in grain $\left(\mathrm{kg} \mathrm{N} \mathrm{ha}^{-1}\right), \mathrm{N}_{\text {fert }}=$ amount of $\mathrm{N}$ mineral fertiliser application rate $\left(\mathrm{kg} \mathrm{N} \mathrm{ha}^{-1}\right)$.

The ratio of $\mathrm{N}$ output in harvested products to $\mathrm{N}$ inputs is the definition for $\mathrm{RE}_{\mathrm{N}}[147,148]$ and the formula was as follows:

$$
\mathrm{RE}_{\mathrm{N}}=\mathrm{N}_{\mathrm{g}} / \mathrm{N}_{\text {input }}
$$

where, $\mathrm{N}_{\mathrm{g}}=$ quantity of $\mathrm{N}$ in grain, $\mathrm{N}_{\text {input }}=$ total $\mathrm{N}$ input.

\section{Factors Affecting Nitrogen Use Efficiency}

Every genotype has its special functional and morphological characteristics that affect $\mathrm{N}$ uptake and the use of absorbed N; thus, species and cultivars are expected as the main factors affecting NUE [149]. However, Burns [150] opined that when subjected to different levels of $\mathrm{N}$ availability, the same genotype can show different NUEs. It is the view of Han et al. [151] that besides genetics, there other factors need to be considered such as the interaction between water availability with $\mathrm{N}$ uptake, interaction between $\mathrm{C}$ metabolism and $\mathrm{N}$ utilisation and interaction between macro and micronutrients. In addition, improving NUE depends on factors such as $\mathrm{C}$ status, water, soil type, temperature and light as these factors affect $\mathrm{N}$ uptake, assimilation and remobilisation efficiency because components of NUE intermingle in numerous and complex ways with other metabolic pathways [138]. Environmental factors such as soil texture, temperature and rainfall affect crop development and growth or the availability of $\mathrm{N}$ in the soil through mineralisation of soil organic matter, organic fertilisers and on nitrate leaching [152] thus, affecting NUE. In addition, factors such as environmental regulation changes, water quality concerns and $\mathrm{N}$ fertiliser price fluctuations $[153,154]$ partially cause low NUE in corn production $[135,155]$. Apart from environmental conditions inhibiting microbial activities, potential limiting factors are physical protection of organic matter within soil matrix, complexation with soil minerals, rhizodeposition or alternative source of low molecular weight of $C$ and chemical recalcitrance $[156,157]$. Achieving synchrony between plant demand and $\mathrm{N}$ supply optimally without deficiency or over-supply is the key for optimising trade-offs between yield, income and environment. Thus, agricultural systems need to work within a 'safe operating space' for N use [158] where NUE is neither low that large amounts of reactive $\mathrm{N}$ are lost to the environment, nor high that soils are degraded.

\section{Ammonium Adsorption and Desorption}

Buss et al. [159] reported that the reactive processes controlling subsurface movement for $\mathrm{NH}_{4}{ }^{+}$include sorption causing cation exchange and biological degradation. Charcoal is one of the highly efficient adsorbents to remove excessive application of $\mathrm{N}$ fertilisers, organic and inorganic contaminants and heavy metals because of its potential physicochemical properties such as large internal surface area, well developed porous structure, wide spectrum of surface functional groups, high cation exchange capacity, water holding capacity and low bulk density. In order to understand the adsorption mechanism of charcoal, the nature of the $\mathrm{NH}_{4}{ }^{+}$as an adsorbate should be known. Furthermore, the physical and chemical properties of the organic and inorganic compounds with surface 
functional groups of the charcoal is needed. Similar to biochar, charcoal adsorbs $\mathrm{NH}_{4}{ }^{+}$via electrostatic exchange with cationic functional groups on the surface of charcoal because of its abundant negatively charged surfaces. Furthermore, the CEC of charcoal is one of the most vital factors affecting $\mathrm{NH}_{4}{ }^{+}$adsorption. Amending soils with charcoal can enhance retention of $\mathrm{NH}_{4}{ }^{+}$in soils because of its high affinity for $\mathrm{NH}_{4}{ }^{+}$sorption compared with soils. However, at low $\mathrm{pH}$ values, the $\mathrm{NH}_{4}{ }^{+}$adsorption capacity decreases because at low $\mathrm{pH}$, competition between $\mathrm{H}^{+}$and $\mathrm{NH}_{4}{ }^{+}$for the active sites of the charcoal surface increases, resulting in low $\mathrm{NH}_{4}{ }^{+}$adsorption capacity [160]. Conversely, when $\mathrm{pH}$ values are higher than 8 , the $\mathrm{NH}_{4}{ }^{+}$ions are transformed to $\mathrm{NH}_{3}$ gas, causing depletion in $\mathrm{NH}_{4}{ }^{+}$ adsorption capacity. Therefore, the optimum $\mathrm{pH}$ for $\mathrm{NH}_{4}{ }^{+}$adsorption ranges between 5 to 8 [161-163]. The relevance of $\mathrm{pH}$ in cation sorption is well established because it affects the chemical speciation of the $\mathrm{NH}_{4}{ }^{+}$in solution as well as the ionisation of chemically active sites on the sorbent. As a result, the net charge of the sorbent surface play an important role in sorption processes, and analysis of protonation-deprotonation behaviour of sorbent materials in aqueous conditions is significant in explaining sorption mechanisms [164]. The $\mathrm{pH}$ at which the sorbent surface charge becomes zero is referred to as the point of zero charge (PZC). At this $\mathrm{pH}$, the charge of the positive surface sites is equal to the charge of negative surface sites. The point of zero charge enables to hypothesise on the ionisation of functional groups and their interactions with $\mathrm{NH}_{4}{ }^{+}$in the solution. The $\mathrm{pH}$ of the solution is higher than point of zero charge, indicate that the sorbent surface such as charcoal and wood ash are negatively charged enable the interaction between positive ions such as $\mathrm{NH}_{4}{ }^{+}$[164]. Moreover, the knowledge of point of zero charge of charcoal and wood ash provides information about the possible attraction and repulsion between charcoal and wood ash and $\mathrm{NH}_{4}{ }^{+}$ions. However, it also allows to ensure that electrostatic force is one of the mechanisms that occurs in $\mathrm{NH}_{4}{ }^{+}$sorption. Even though Makoto and Koike [165] believe that the adsorption capacity of charcoal affects $\mathrm{N}$ dynamics differently because the function of charcoal as adsorbent is relatively short although it has the potential to remain in soils for thousands of years, as its pores become clogged [165]. The adsorption process commonly examined to obtain optimum conditions based on mathematical models are obtained from laboratory results such as pseudo-first order, pseudo-second order and intra-particle diffusion for kinetics studies whereas, Langmuir and Freundlich models are for isothermal studies. Adsorption of wood ash in soils enhances microbial growth to immobilise $\mathrm{C}$ in addition to reducing nutrient leaching through improved soil stability. Similar to charcoal, adsorption of $\mathrm{NH}_{4}{ }^{+}$on the surface of the wood ash is influenced by its specific surface area and porosity. Even though charcoal exhibits higher adsorption capacity, ash has a potential as an intermediate adsorption capacity [166]. Gómez-Rey et al. [167] opined that in $\mathrm{N}$ limited soils, co-application of wood ash and $\mathrm{N}$ fertiliser balances soil $\mathrm{N}$ immobilisation.

\section{Kinetics of Sorption Model}

Özcan et al. [168] described that the kinetics of adsorption is one of the key characteristics defining the efficiency of adsorption because the study of kinetics model establishes important information for the reaction pathways and sorption reaction mechanism [169,170]. Moreover, the kinetics of sorption depends on the physical and chemical characteristics of sorbent and sorbate $[169,171,172]$. To determine adsorption isotherms, the adsorption kinetics of $\mathrm{NH}_{4}{ }^{+}$need to be studied using three kinetics models such as the pseudo-first order, pseudo-second order kinetic models and intra-particle diffusion model (Table 4) $[163,173,174]$. 
Table 4. Kinetic Models of Ammonium Sorption.

\begin{tabular}{cccc}
\hline Kinetic Models & Equation & Plot & Reference \\
\hline Pseudo-first order & $\log \left(\mathrm{q}_{\mathrm{e}}-\mathrm{q}_{\mathrm{t}}\right)=\log \left(\mathrm{q}_{\mathrm{e}}\right)-\frac{\mathrm{k}_{1} \mathrm{t}}{2.203}$ & $\log \left(\mathrm{q}_{\mathrm{e}}-\mathrm{q}_{\mathrm{t}}\right)$ vs. $\mathrm{t}$ & {$[175]$} \\
Pseudo-second order & $\frac{\mathrm{t}}{\mathrm{q}_{\mathrm{t}}}=\frac{1}{\mathrm{k}_{2} \mathrm{q}_{\mathrm{e}}{ }^{2}}+\frac{\mathrm{t}}{\mathrm{q}_{\mathrm{e}}} \mathrm{v}_{0}=\mathrm{k}_{2} \times \mathrm{q}_{\mathrm{e}}$ & $\frac{\mathrm{t}}{\mathrm{q}_{\mathrm{t}}} \mathrm{vs.} \mathrm{t}$ & {$[172,175]$} \\
Intra-particle diffusion & $\mathrm{q}_{\mathrm{t}}=\mathrm{k}_{\mathrm{i}} \times \mathrm{t}^{1 / 2}+\mathrm{c}_{\mathrm{i}}$ & $\mathrm{q}_{\mathrm{t}}$ vs. $\mathrm{t}^{0.5}$ & {$[172]$} \\
\hline
\end{tabular}

Where: $\mathrm{q}_{\mathrm{e}}$ is amount of ions adsorbed per unit mass of the adsorbent at equilibrium time, [mg/g]; $\mathrm{q}_{\mathrm{t}}$ is amount of ions adsorbed per unit mass of the adsorbent at time $\mathrm{t}(\mathrm{mg} / \mathrm{g}) ; \mathrm{t}$ is contact time $[\mathrm{min}] ; \mathrm{k}_{1}$ is pseudo-first order rate constant $[1 / \mathrm{min}] ; \mathrm{k}_{2}$ is the pseudo-second order rate constant ( $\left.\mathrm{g} / \mathrm{mg} \mathrm{min}\right) ; \mathrm{k}_{\mathrm{i}}$ is intra-particle diffusion constant $\left(\mathrm{mg} / \mathrm{g} \min ^{\frac{1}{2}}\right) ; \mathrm{C}_{\mathrm{i}}$ is intercept directly propotional to the thickness of the boundary layer $(\mathrm{mg} / \mathrm{g})$ found in [176].

\section{Adsorption Isotherm}

Yuan et al. [177] defined adsorption isotherm as the relationship between concentration of the solute in the solution and quantity of the adsorbate adsorbed by sorbent in equilibrium at constant temperature. The Langmuir isotherm is based on the assumption that uptake of $\mathrm{NH}_{4}{ }^{+}$occurs by monolayer adsorption without any interference between adsorbed ions on a homogeneous surface $[178,179]$. This isotherm model represents the equilibrium distribution between solid and liquid phases of $\mathrm{NH}_{4}{ }^{+}$ions. The underlying hypothesis of this model it is for all active adsorption sites with same energy. The linear form of Langmuir equation is reported as [180,181]:

$$
\frac{C_{\mathrm{e}}}{\mathrm{q}_{\mathrm{e}}}=\frac{1}{\mathrm{bq}_{m}}+\frac{C_{\mathrm{e}}}{\mathrm{q}_{m}}
$$

where, $C_{e}(\mathrm{mg} / \mathrm{L})$ is the equilibrium concentration in solution, $\mathrm{q}_{\mathrm{e}}(\mathrm{mg} / \mathrm{g})$ is the amount of $\mathrm{NH}_{4}{ }^{+}$ion adsorbed at equilibrium. $\mathrm{q}_{m}(\mathrm{mg} / \mathrm{g})$ is the maximum $\mathrm{NH}_{4}{ }^{+}$ion uptake per unit mass of the adsorbent, which relates to adsorption capacity. $b$ is the Langmuir constant $(\mathrm{L} / \mathrm{mg})$ which relates to the adsorption rate. The $\mathrm{q}_{m}$ and $\mathrm{b}$ can be determined from $C_{\mathrm{e}} / \mathrm{q}_{\mathrm{e}}$ versus the $C_{\mathrm{e}}$ plot which gives a straight line of slope $1 / \mathrm{q}_{m}$ and intercept $1 /\left(\mathrm{bq}_{m}\right)$.

The essential characteristics of Langmuir adsorption isotherm is described in terms of dimensionless constant known as separation factor or equilibrium parameter as [182]:

$$
\mathrm{x}=\mathrm{abC} /(1+\mathrm{aC})
$$

where, $x$ is the total amount of $\mathrm{NH}_{4}{ }^{+}$adsorbed $(\mathrm{mg} / \mathrm{kg})$, $a$ is the constant related to the binding strength $(\mathrm{mg} / \mathrm{kg}), \mathrm{b}$ is a sorption maximum, $\mathrm{C}$ is the $\mathrm{NH}_{4}{ }^{+}$concentration remaining in the solution after the equilibrium $(\mathrm{mg} / \mathrm{kg})$.

Hui et al. [183] reported that the Freundlich isotherm used to designate the adsorption of inorganic and organic constituents in solution. This Freundlich isotherm model involves heterogeneous sorption and it suits a non-ideal sorption. It describes multilayer adsorption. The isotherm is expressed as follows [179]:

$$
\log \mathrm{q}_{\mathrm{e}}=\log \mathrm{K}_{\mathrm{f}}+\frac{1}{n} \log \mathrm{C}_{\mathrm{e}}
$$

where, $C_{e}$ is the equilibrium concentration in liquid phase $(\mathrm{mg} / \mathrm{L}), \mathrm{q}_{\mathrm{e}}$ is the maximum amount of $\mathrm{NH}_{4}{ }^{+}$adsorbed at equilibrium $[\mathrm{mg} / \mathrm{g}], \mathrm{K}_{\mathrm{f}}$ is the Freundlich adsorption capacity and $1 / n$ is the sorption constant having a value range between 0 and 1 .

Another approach isotherm studies is to calculate the partitioning of solution and solid phase known as adsorption-desorption distribution coefficient $(\mathrm{Kd})$. It is also referred to Freundlich solid-water adsorption capacity $\left(\mathrm{K}_{\mathrm{f}}\right)$. Distribution coefficient is the ratio of concentration in the solid phase to concentration in the solution phase. It is an essential information for understanding the mobility of a compound in the environment and its distribution between water, sludge, soil and sediment. The distribution of a chemical between water and soil, sludge and sediment are determined by the chemical properties as well as the matrix. In agricultural fields, temperature and rainfall affect the distribution coefficient. The low $\mathrm{Kd}$ values suggest weak interaction between $\mathrm{NH}_{4}$ and surface of 
charcoal [184]. Due to this, the $\mathrm{NH}_{4}$ ions on the surface of the charcoal and wood ash can easily interchange with other's cationic species.

Brunauer-Emmett-Teller (BET) theory is another well-known approach for characterisation of catalyst, adsorbents and natural or artificial porous materials. This BET is a typical approach for calculating specific surface area by estimating $\mathrm{N}$ adsorption isotherms for determining specific surface area [185]. BET theory is related to Langmuir isotherms which were limited to monolayers. BET assumes that adsorbent surfaces are ideally flat and that gas molecules can adsorb on this surface of an adsorbed molecule [186]. Additionally, BET theory assumes that all layers involved in multilayer adsorption are in equilibrium [187]. This phenomenon is stimulated by Van der Waals forces generated by the adsorbate layer which is made up of atoms, ions or molecules on the surface of a charcoal that adsorbs their particles [186]. The amount of the adsorbed $\mathrm{N}$ gas on charcoal as adsorbent material can be correlated with its surface area. The BET surface area of charcoal increases with increasing pyrolysis temperature, especially at $500^{\circ} \mathrm{C}$ to $700{ }^{\circ} \mathrm{C}$. [188] because, volatiles are rapidly released at high temperature, resulting in the rapid formation of charcoal porous structure. The adsorption energy difference between the first and second layer is linked to the dimension less $C$ parameter.

$$
C \approx \exp \left(\left(\mathrm{E}_{1}-\mathrm{E}_{2}\right) / \mathrm{RT}\right)
$$

where, $E_{1}$ and $E_{2}$ the molar adsorption energy for first and second layer. The adsorption energy of the third and higher layer is equal to the second. In general, it is the quantity of interest since it produces the specific surface area when multiplied by the cross-sectional area of the sorbate. The BET equation is expressed as follows [189]:

$$
\left(\left(P / P_{0}\right) / n\left(1-P / P_{0}\right)\right)=\left(1 / n_{m} C\right)+\left((c-1) /\left(n_{m} C\right)\right)\left(P / P_{0}\right)
$$

where, $P$ is the pressure, $P_{0}$ is the saturation pressure of a substance being adsorbed at the adsorption temperature, $n$ is the specific amount of adsorbed gas at the relative pressure $P / P_{0}, n_{m}$ is the monolayer capacity of the adsorbed gas, $C$ is the BET constant which is exponentially related to the energy of monolayer adsorption. The shape of an isotherms in the BET range obtained from parameter $C$. When the maxima arrangement approach is used, the values of $C$ are positive, this avoids erroneous $n_{m}$ evaluation from occurring when an improper pressure range is used to construct a BET plot [186]. However, because this approach is based on gas adsorption, limitations are commonly associated with monolayers. For example, the validity of BET monolayer capacity $\left(n_{m}\right)$ is problematic. Moreover, the monolayer structure is not the same on all the surfaces especially when $\mathrm{N}_{2}$ isotherms are used. Additionally, according to the International Union of Pure and Applied Chemistry (IUPAC), wood charcoal exhibits type $1 \mathrm{~N}_{2}$ adsorption isotherm and $\mathrm{H}$ 4 hysteresis loop representing narrow slit pores in the microspores region (Average pore radius < $50 \AA$ ) [190]. Based on the BET theory that significant overlap between monolayer and multilayer coverage would undermine the assumption that adsorption occurs via formation of multilayer [191]. Mel'gunov and Ayupov [186] believe that if the value of cross-sectional molecular area is known, the BET surface area analysis theory could be applied for any adsorbates and adsorbents at any temperature. It is the view of Van Erp and Martens [185] that reproducibility issues develop because of a systematic divergence between BET theory and the actual experimental condition, in which the hypothesised assumptions are not completely achieved.

\section{Types of Spectroscopy}

X-ray absorption spectroscopy (XAS) consists of extended $\mathrm{x}$-ray absorption fine structure (EXAFS). X-ray absorption spectroscopy measures the $\mathrm{x}$-ray absorption coefficient of a material as a function of energy. Each element has a unique set of absorption edges that correspond to the different binding energies of its electron, resulting in XAS element selectivity. Extended $x$-ray absorption fine structure, being a very sensitive technique, is a convenient tool to determine the chemical state of species that may exist even at very low 
concentrations. Synchrotron-based X-ray absorption fine structure spectroscopy has been reported as a powerful tool for elucidation of metal speciation in soils treated with soil amendments [192]. Energy dispersive EXAFS aids in the determination of structural and kinetic characteristics in supported metal catalysts for reactions that occur on a timescale of a few seconds [164]. X-ray photoelectron spectroscopy (XPS) is one of the standard tools for surface characterisation. The XPS analysis is performed to identify the elemental composition such as carbon, oxygen and nitrogen, types of acidic functional groups and their relative percentage on the surface of charcoal. The formation of surface oxygen on charcoal enhances the oxygen containing complexes to improve ion exchange properties during adsorption. However, it should be noted that XPS analysis estimates the structure to a few nanometers in depth [193].

Fourier transform infrared spectroscopy (FTIR) is one of the techniques that determines the structure, composition and size of nanoparticles. It is a technique for measuring the absorption of electromagnetic radiation with wavelengths in the mid-infrared range (4000-400 $\mathrm{cm}^{-1}$ ) [164]. In general, charcoal is composed of $C$ atoms, and heteroatoms such as $\mathrm{O}, \mathrm{H}, \mathrm{N}$, and $\mathrm{S}$. As a result, several functional groups dominate the surface of the charcoal and FTIR provides information on these chemical structures [194]. The presence of more acidic functional groups on the surface of the charcoal promotes cation adsorption such as $\mathrm{NH}_{4}{ }^{+}$during chemisorption process [193]. The most prominent bands representing functional groups on the surface of charcoal are $\approx 3500,1700,1610,1420$, and $1140 \mathrm{~cm}^{-1}$ indicating free or intermolecular bonded $\mathrm{OH}$ groups, carbonyl $(\mathrm{C}=\mathrm{O})$ stretching vibrations of carboxyl groups, ketones or aldehydes, $\mathrm{C}=\mathrm{C}$ double bonds aromatic rings, and ether C-O stretching bonds, respectively [194]. Charcoal demonstrates $\mathrm{OH},-\mathrm{CH}$ and $\mathrm{C}=\mathrm{O}$ stretching in the regions of 3500, 2926 and $2858 \mathrm{~cm}^{-1}$ [195]. In addition, well distinguished peaks are observed near 1100 and $780 \mathrm{~cm}^{-1}$ and they represent $\mathrm{OH}$ bending and $=\mathrm{CH}_{2}$ bands [196]. The point of zero charge values for charcoal range from 7.4 to 9.9 [191]. Thus, at normal $\mathrm{pH}$ (6 to 7), charcoal is protonated, to sorb anionic contaminants via electrostatic interaction [197].

\section{Ashes and Their Chemical Composition}

Wood ash is considered as significant source of mineral, a product of incomplete combustion of wood containing inorganic and organic compounds [198] such as mixtures of oxides, carbonates, hydroxides, silicates and its $\mathrm{N}$ is low because $\mathrm{N}$ aquires volatilised during combustion [199]. Ash can be utilised as an alternative chemical fertiliser that can act as a liming agent to improve nutrient cycling because of its high solubility and availability of macronutrients for plants. The relative amounts of the major nutrients in ash are in the order of $\mathrm{K}>\mathrm{Mg}>\mathrm{Ca}>\mathrm{P}$ [200]. These nutrients are important in the formation of nucleotides, phosphatides, chlorophyll and alkaloids, synthesising enzymes, vitamins and hormones [201]. Pitman [202] stated that depending on growth conditions, different wood have several amounts of mineral compounds. For example, hardwood ash has a lesser amount of $\mathrm{Ca}$ and Si but is higher in $\mathrm{K}$ and $\mathrm{P}$ than softwood ash.

\section{Properties of Ashes}

The properties of ash differ depending on the amount of bark burned, species of the plant, growth conditions and contamination of materials from harvest operation such as soil [203]. The temperature during combustion is also important. For example, temperature below $500{ }^{\circ} \mathrm{C}$ produces carbonates and bicarbonates whereas at or above $1000{ }^{\circ} \mathrm{C}$, the most prevalent compounds are oxides and hydroxides [204].

\section{Use of Ashes in Agriculture}

According to Van Laer et al. [32], wood ash has been utilised as a soil conditioner. Wood ash which is produced through combustion is not only alkaline but it also high in soluble macronutrients such as $\mathrm{Ca}, \mathrm{K}, \mathrm{P}$ and $\mathrm{Mg}$ [33]. Moreover, wood ash has a potential to reduce nutrient loss from crop harvesting and it is also ideal for acid soils that are highly weathered because of the acid neutralising capacity of wood ash. When soil acidity 
decreases, base saturation and microbial activity increase [34]. However, with time, the ash as soil amendment reduces because of biogeochemical interactions between amendment and soil profile $[35,36]$. The adsorption properties of wood ash are influenced by its specific surface area. This can also be associated with the pore size that affects the type of molecules that can be adsorbed on the surface, wood ash and $C$ residues with larger surface area increased the adsorption properties [37]. Moreover, wood ash can increase water holding capacity, moisture content and nutrient availability because its hydrophilic property enhances soil water retention [38], microbial activities [205,206], improve growth and crop yields [207-209] and availability of P, K, and B. Over utilisation of wood ash could damage plants because it contains some toxic substances such as Caesium-137 as radioactive elements and some elements such as $\mathrm{As}, \mathrm{Pb}, \mathrm{Zn}, \mathrm{Ni}, \mathrm{Co}$, and $\mathrm{Cu}$ which can be toxic to plants and cause environmental problems [210]. These toxic substances can disturb nutrient cycling in soils and microbiological processes if excess wood ash is applied which adversely affect plant growth [198,211]. Nabeela et al. [198] reported that application of wood ash resulted in increase in bioaccumulation of trace elements in Brassica napus L. seedlings and the order of bioaccumulation was $\mathrm{Fe}>\mathrm{Zn}>\mathrm{Pb}>\mathrm{Co}>\mathrm{Cu}>\mathrm{Cd}>\mathrm{Ni}$.

\section{Mechanism of Bark Ash on the pH of Tropical Acid Soils}

Augusto et al. [212] reported that, different oxides formed during combustion and consequent aeration can cause formation of carbonates in ash, making the ash alkaline (pH 8 to 13). Moreover, utilisation of ash as soil amendment can return essential nutrients back to the soil apart from neutralising soil acidity. The rapid changes in $\mathrm{pH}$ are influenced by carbonates, oxides, hydroxides and hydrogen carbonates. Addition of ash does not only increase soil $\mathrm{pH}$ but it also indirectly stimulates microbial activities [213] which play an important role in decomposition and mineralisation. The use of wood ash caused rapid changes in the chemical properties of the soil particularly the topsoil [214]. Arvidsson et al. [215] revealed that, the neutralising effects of wood ash are very minimal or none in the deeper layers.

\section{Charcoal}

Charcoal is a solid carbonaceous residue which is produced by heating through slow and rapid pyrolysis, gasification and hydrothermal carbonisation under oxygen-deficient conditions [15]. Charcoal is produced through slow pyrolysis [16] and it is highly resistant to decomposition $[17,18]$. Charcoal in soils has been well recognised to influence the nature of sorption mechanism and improves sorption of organic pollutant $[19,20]$. Charcoal can positively impact on soil processes and properties for the first few decades after its formation $[17,21,22]$. In carbonaceous materials, adsorption is regulated by physical and chemical structures [20].

Adsorption is commonly used as an efficient physical separation mechanism to remove or reduce the concentration of a diverse variety of dissolved contaminants whether organic or inorganic pollutants [23]. Charcoal structure reflects the morphology of its raw material [24]. A typical charcoal consists of $C, H, N, S$, ash, and oxygen [25]. In addition, its structure, composition and characteristics such as particle size distribution, moisture content, density, ash content and $\mathrm{pH}$ depend on the form, nature and origin of raw material, in addition to the state of thermal conversion cycle [26]. Furthermore, $C$ materials are resistant to toxic conditions and corrosive environments such as basic and acidic conditions. The utilisation of $\mathrm{C}$ as the material is due to its special structure and electrical conductivity [31]. Factors that affect the properties of charcoal are the form of organic matter used, the charring environment and additions during the charring process. The source of charcoal material has significant impact on the direct effects of the alteration of charcoal amendments on nutrient contents and availability. Moreover, microbes have significant impact on the properties of charcoal [30] because surface oxidation is the most significant coal weathering mechanism contributing to an increase in functional groups such as carboxyl and carbonyl at the exchange sites [216]. Losses of charcoal from soil occur in different ways such as erosion by surface runoff $[30,217,218]$, biotic, and abiotic degradation [30]. In addition, alteration of charcoal physical, chemical and biological 
properties can occur because of environmental exposure and this cause long terms changes in its hydrological, microbial and nutrient retention services [21,219,220]. Multiple processes including chemical and physical weathering [221], infilling pores with soil-mineral or soil-humic substances [222] and biological alteration [222-224] can significantly alter the density and porosity of charcoal after being introduced to the environment.

\section{Charcoal Porosity}

Depending on its raw material and production temperature, charcoal is highly porous with approximately 55 to $85 \%$ total pore volume. The pore size ranges between subnanometers and tens of micrometers $[225,226]$. Charcoal pores are divided into macropores, meso-pores and nano-pores [227]. Approximately 95\% of charcoal's total porosity is dominated by macro pores with $>50 \mathrm{~nm}$ in size, that are important as microbial habitats and water retention. Meso-pores $(2-50 \mathrm{~nm})$ and nano pores $(<2 \mathrm{~nm})$ are essential for nutrient retention and charcoal's active surface area represent approximately less than $5 \%$ of its total porosity [225,226,228] (Figure 1). Trubetskaya [229] opined that charcoal from hardwood species is less porous than softwood leading to its lower reactivity at high temperature pyrolysis. The distribution of pore size and porosity of charcoal also influence its hydrological and ecological capabilities in soils [230-232]. The distribution of the pores is significant as an ecological niche for soil microbes because micron-sized pores are abundant in biomass-derived charcoal, and inherited from cellular plants, are suitable for soil microbes such as most bacteria and fungi $[226,233]$. A charcoal with high volumes of pores can increase soil total porosity and water holding capacity. Several pore sizes distribution enhance retention of plant available water [232]. In most literature, adsorption takes place in micropores, nevertheless macropores and mesopores contribute as a passage for the absorbate to the micropores, because only a small number of the pores are on the outer surface of the charcoal.

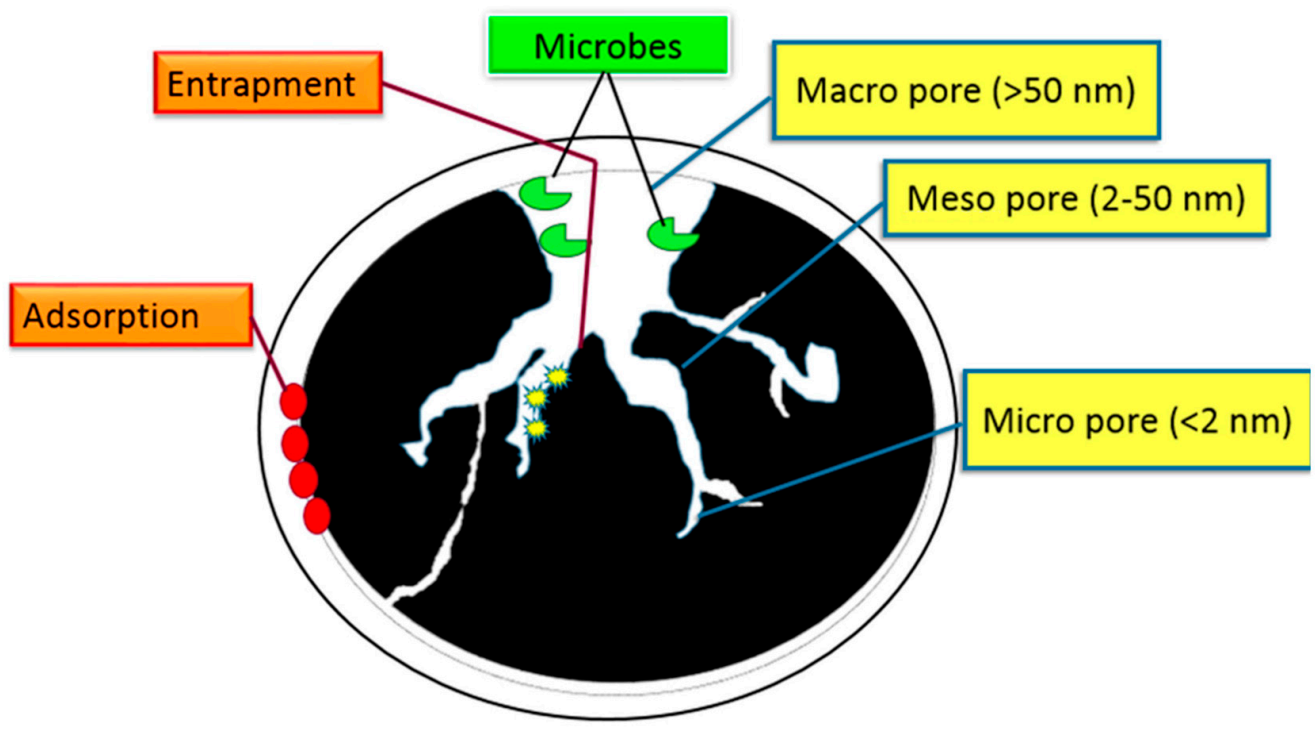

Figure 1. Illustration of pore distribution [227].

\section{Charcoal as an Amendment That Retains Nutrients in Agriculture}

In arid and humus-poor areas in particular, charcoal can significantly improve soils in these regions because it is resilient in soil, thus it decomposes slowly over the long term [25]. Hermann et al. [234] reported that, approximately 50 to $80 \%$ of charcoal C is integrated in soil system. Previous studies demonstrated that charcoal has some soluble iron oxides to increase soil $\mathrm{pH}$. This is important for plant growth because it improves soil fertility, besides reducing soil tensile strength to facilitate root growth and root predation, and enabling seeds germination [235-237]. Charcoal has different inorganic and organic forms of $\mathrm{N}$ and $\mathrm{P}$ such as $\mathrm{NO}_{3}{ }^{-}, \mathrm{NH}_{4}{ }^{+}$, amide groups and ortho-P $[27,28]$. However, the 
concentrations of these nutrients depend on the production temperature and its sources. For example, charcoals produced at lower temperature have more $\mathrm{NH}_{4}{ }^{+}$, whereas charcoals produced at higher temperature tend to be high in $\mathrm{NO}_{3}{ }^{-}$, and charcoal produced from plant residues usually have higher nutrient content than charcoal generated from ligno-cellulosic feedstocks [29]. Not only the contents of nutrients, but also the conservation of nutrients can be enhanced by applying charcoal to soils. This is particularly relevant in heavily weathered soils with poor ion retention ability [30]. Moreover, charcoal has high-specific surface area because of its porous structure, surface electrostatic properties $[236,238]$ and rich in high concentration mineral nutrients present after formation on its surfaces $[29,239,240]$. These properties enable charcoal to alter nutrient accessibility through inputs of the nutrient it is contain [30,241], increases $\mathrm{pH}$ and soil water holding capacity [22,242,243], promote microbial activity and nutrient fluxes $[29,236,244]$ and increase sorption of secondary compound that impede soil processes such as phenolics [21,245]. Furthermore, addition of charcoal to soils enhances seed germination, plant growth and yields particularly in the tropics [30]. Added charcoal not only act as soil conditioner but also acts as an amendment to increase $\mathrm{CEC}$, reduce the $\mathrm{Al}$ saturation of acid soils, and improve free bases availability such as $\mathrm{Ca}, \mathrm{K}$ and $\mathrm{Mg}$ [30]. However, excessive addition of charcoal or coal derived humic acids can have adverse effects on crop production [30].

\section{Nutrient Sorption Mechanism of Charcoal}

Charcoal as an amendment has influences the diversity and composition of soil microbial communities [246-248] by altering the soil microclimate such as $\mathrm{pH}$, water holding capacity, bulk density, cation exchange capacity and structure of the soil [249-251]. Makoto and Koike, [165] revealed that charcoal influences saprotrophic microbes. In addition, charcoal provides nutrient and source of $C$ directly and indirectly to microbes because of its high surface area. Its ability to adsorb nutrient making it available for microbe's consumption $[19,252,253]$. The large surface area and porosity of charcoal provide habitat for soil microbes from soil predators $[35,254]$. It can remain in the soil ecosystem for hundreds to thousands of years because its aromatic structure is highly recalcitrant to soil microbial decomposition [249]. However, Khodadad et al. [247] opined that alteration of the soil microbial community stimulated by charcoal differ according to soil type and the raw materials from which the charcoal was produced. Makoto et al. [255] reported that charcoal buried in subsurface soil had a positive effect on seedling growth and rhizosphere compare with charcoal deposited on the soil surface. Moreover, there are several major ion sorption mechanisms onto charcoal such as surface precipitation, chemical reaction with surface functional groups, entrapment in the solution into interior pores and electrostatic adsorption [256,257]. Gierak and Lazarska [258] reported that the adsorption of ions does not only depend on specific surface area of charcoal as an adsorbent, but presence of the surface groups is also important. This is because the oxidation of active $\mathrm{C}$ increases amount of oxygen functional groups on the surface of charcoals, which results in an increase in polarity and hydrophilicity of the surface of charcoals. Content and the nature of the emerging oxygen functional groups [259,260] affects the conditions applicable during modification of $\mathrm{C}$ as well as applied oxidisers. The surface functional groups include carboxyl, carbonyl, phenol, quinone, lactone and other groups bound to the edge of graphite-like layers enable the complex formation between the adsorbed molecule and the carbonyl group of the charcoal which makes it suitable as adsorbents. In addition, Jankowska et al. [261] stated that the $C$ material which is oxidised in the liquid phase or chemically oxidised in the gas phase within a range of $300{ }^{\circ} \mathrm{C}$ to $500^{\circ} \mathrm{C}$ can exchange cations.

\section{Water Retention Mechanism of Charcoal}

Similar to biochar, addition of charcoal to soils can have direct and indirect effects on soil water retention. The direct effect is due to the porosity of charcoal and high internal surface area where the retention of water occurs by capillarity. Overall, this can improve soil water content, porosity, in addition to reducing mobility of water, thus reducing water stress in plants. Improvement in soil structure and aggregation are the indirect effects of water retention in soil influenced by charcoal $[238,260]$. 


\section{Nitrate Retention Mechanism by Charcoal}

Nitrate is negatively charge, highly soluble in water and it moves with soil water. Commonly, soils are unable to adsorb nitrate because at their natural $\mathrm{pH}$, anion exchange capacity is insufficient. Due to its negative charge, $\mathrm{NO}_{3}{ }^{-}$is repelled by the negatively charge soil colloids. With the aid of charcoal's unique pore structure, soil water is trapped inside charcoal pores and $\mathrm{NO}_{3}{ }^{-}$remain in available formed until they are taken up by plant. Figures 2 and 3 demonstrate the mechanisms of how charcoal prevents leaching of $\mathrm{NO}_{3}{ }^{-}$in soil water during heavy rainfall. However, the role of charcoal in retaining $\mathrm{NO}_{3}{ }^{-}$depends on its adsorption capacity such as raw material used and temperature for pyrolysis [105].

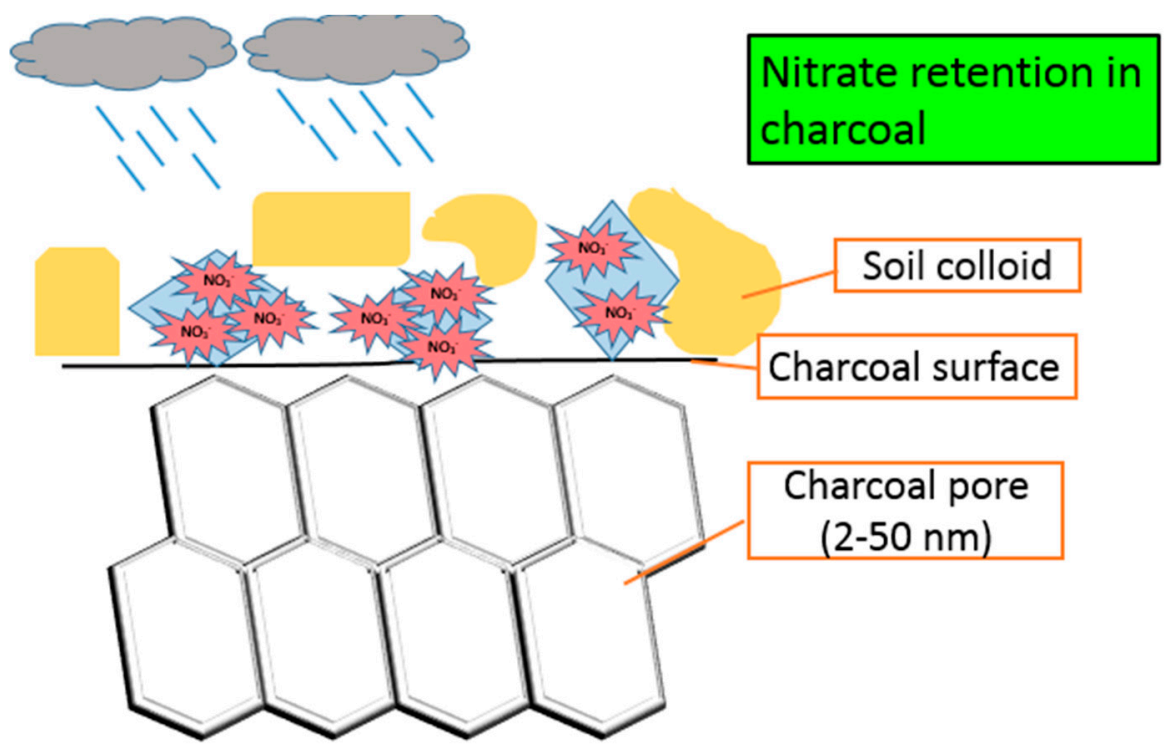

Figure 2. Schematic illustration of the process of leaching with charcoal.

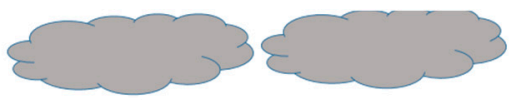

Nitrate retention in charcoal

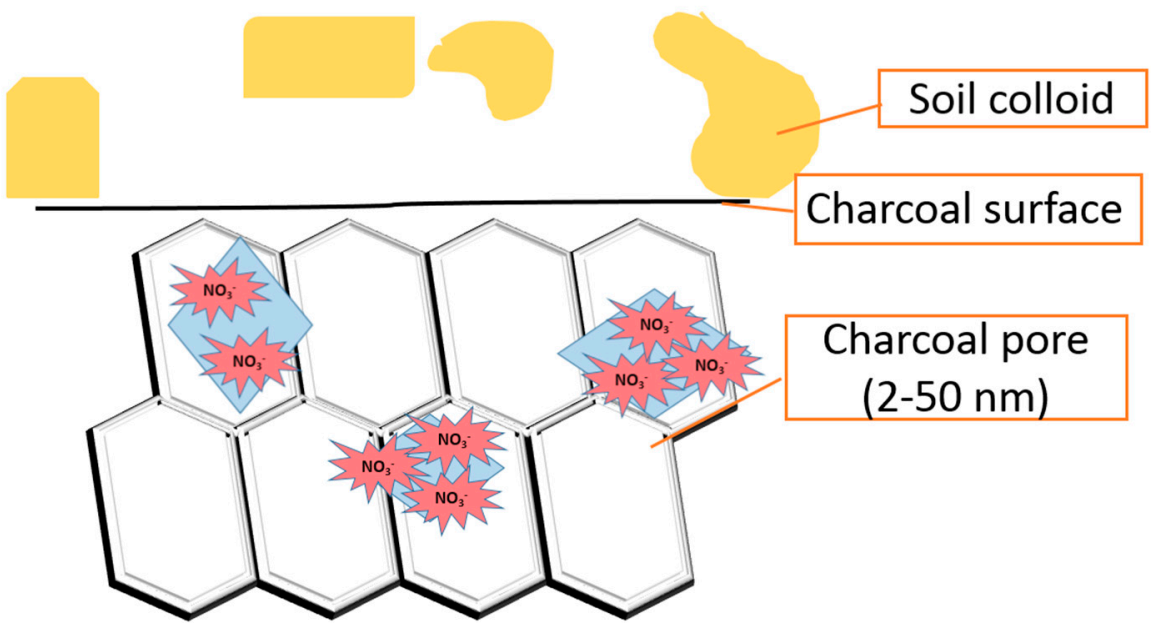

Figure 3. Schematic illustration of the entrapment of nitrate in soil water inside charcoal pores.

\section{Ammonium Retention Mechanism by Charcoal}

Similar to biochar, charcoal's capacity to sorb $\mathrm{NH}_{4}{ }^{+}$ions is because of its physical and chemical properties. Charcoal is an amendment with high-specific surface area and high 
in CEC because of its porous structure, surface electrostatic properties [238] and rich in high concentration mineral nutrients present after formation on its surfaces $[29,239,240]$. These properties enable charcoal to alter nutrient accessibility such as retaining $\mathrm{NH}_{4}{ }^{+}$ions through inputs of the nutrient it contains [30,241]. The combination of ash and charcoal as amendments will increase soil $\mathrm{pH}$ and enhance $\mathrm{NH}_{4}{ }^{+}$retention at charcoal surface area. Increase in $\mathrm{pH}$ will cause dissociation of $\mathrm{H}^{+}$from hydroxyl and carboxylate groups, which provide negatively charged surface adsorption sites enables $\mathrm{NH}_{4}{ }^{+}$ions to be retained and remain in its available form. This $\mathrm{NH}_{4}{ }^{+}$retention process is also called $\mathrm{NH}_{4}{ }^{+}$adsorption in which $\mathrm{NH}_{4}{ }^{+}$ions are attached to negatively charged surface that can improve nitrogen availability by remain available to crops and being protected from losses due to leaching.

\section{Adverse Effect of Charcoal as Soil Amendment}

Pyrolysis of biomass to produce charcoal does not only pledge benefits but it also has its adverse effect. Freddo et al. [262] reported that one of the adverse effects of using charcoal as soil amendment is its possible contamination with organic and inorganic contaminants such as heavy metals and polycyclic aromatic hydrocarbons (PAH). The pyrolysis technologies can increase the concentration of potential pollutants from raw materials because of mass losses [263,264]. In addition, Chen et al. [265] stated that the content of contaminant such as heavy metals increase with increasing temperature of pyrolysis. For example, Keiluweit et al. [266] informed that at $500{ }^{\circ} \mathrm{C}$ pyrolysis temperature produced maximum amount of PAH in charcoal. Lyu et al. [267] opined that PAH were produced mostly at $300{ }^{\circ} \mathrm{C}$ to $400{ }^{\circ} \mathrm{C}$. Particulate matter and black $\mathrm{C}$ can be emitted during pyrolysis, especially on low technology conditions compared with modern pyrolysis plants with high standard filtration technology. Apart from different types of dioxins found produced at $250{ }^{\circ} \mathrm{C}$ to $900{ }^{\circ} \mathrm{C}$ [268]. Therefore, Shackley et al. [269] suggested health safety and environmental protection when designing the charcoal pyrolysis production technology considering the location of pyrolysis facilities. According to Mohammadi et al. [270] the impact of the toxicities impacted human health is higher particularly when the charcoal is produced in brick kiln, where pyrolysis gases released to the air and not captured.

The addition of charcoal to soils has an inhibitory effect on soil aging. Anyanwu et al. [271] reported that addition of charcoal as soil amendment has negative impacts on earthworms and fungi growth that indirectly leads to reduction of root biomass. This is because decomposition of organic matter has potential to be disturbed by the addition of charcoal as amendment, thus inhibiting fungi growth such as Ascomycota and Basidiomycota by $11 \%$ and $66 \%$, respectively [272]. Several studies reported that weed problem arise with the application of charcoal [273].

\section{Humic Substances}

Humic substances are one of the most important soil components because they form an enormous fractions of soil organic matter in agricultural soils [274]. Based on their solubility in water with various $\mathrm{pH}$ values, humic substances can be classified into three fractions namely humic acids, fulvic acids and humins [274]. Chang et al. [275] revealed that humic acids are insoluble at acidic $\mathrm{pH}$ but soluble in basic $\mathrm{pH}$ whereas humins exhibit low solubility at different $\mathrm{pH}$ levels. The formation of humic substances in ecosystems cause formation of oxygen functional groups such as carboxylic, phenolic, alcoholic and carbonyl [276].

\section{Humic Acids}

Humic acids are organic substances formed from transformation and decomposition of animal, and plant residues through microbial and geochemical activities [277]. Humic acids have a complex surface structure, large specific surface area and abundant functional groups, resulting in having strong adsorption ability [278]. Previous studies reported that humic acids promote improves soil aggregate stability [279], root growth [280], soil $\mathrm{N}$ and P availability [281,282] and crop yield. Humic and fulvic fractions have high capacity for metal binding because of their reactive groups such as carboxyl and phenolic groups [283]. 


\section{Fulvic Acids}

Fulvic acids are known as complex hybrid of organic micro molecules and polymers including weak aliphatic and aromatic organic acids with significant variability of particle structure and composition [284,285]. Fulvic acids consist of aromatic rings with a range of three to five substituents such as hydroxyl, methoxyl, carboxylic groups, sugars, amino acids and aliphatic hydrocarbon groups with some aldehyde and keto functional groups attached to some of the aromatic nuclei [286-288]. The molecular size of fulvic acids ranges from few hundred to thousands atomic units $[284,288]$. In soil systems, the physical and chemical performances of fulvic acids are restricted by factors such as $\mathrm{pH}$, temperature, salinity, climates, plant species and microbial activities and populations. Moreover, their composition depends on plant species which provide the initial material for mineralisation and humification, whereas the formation of fulvic acids is influenced by microbial activities [285,288]. In their solid state fulvic acids can attract each other, exhibit highly electrostatically stable charges and can decompose upon heating without burning through gradual charring process. At $50{ }^{\circ} \mathrm{C}$ irreversible changes occur [288].

\section{Humin}

Approximately 50 to $70 \%$ of the total humic substances on earth is humin [289]. Lehmann and Kleber [290] opined that humins serve as important component in the natural $\mathrm{C}$ cycle through decomposition and $\mathrm{CO}_{2}$ production. Humins are highly resistant to microbial degradation because it is believed that they are the last residual organic matter produced during humification. Humins have large surface area, making it potential adsorbent with numerous functional groups such as esters, polar aromatic groups and methoxy alkanes [291]. Li et al. [292] reported that bacteria community can affect the structure and types of humin precursors.

\section{Changes of Carbon to Nitrogen}

The chemical forms of organic matter added and subsequent form can affect the long term soil C and N sequestration efficiency [293]. Wang et al. [294] revealed that soil C is the principal energy source to soil microorganisms and enzymes whereas the soil $\mathrm{C} / \mathrm{N}$ ratio influences their activity. Soil $\mathrm{C}$ and $\mathrm{N}$ chemical fractions are theorised to correlate with their half-life and stability. Stable organic compounds can be isolated through hydrolysis of soil organic matter with strong acid $[295,296]$ by producing labile proteins, nucleic acids and polysaccharides, whereas leaving non-hydrolysable long-chain aliphatics and aromatics $[297,298]$. The non-hydrolysable C and soil humin fractions are correlated to determine the oldest $C$ fractions with radiocarbon dating [299,300]. Plante et al. [296] stated that, the non-hydrolysable $C$ was more associated with silt compared with clay soil particles. Changes in soil enzymes, could also reflect changes in soil $\mathrm{C}$ and $\mathrm{N}$ which play vital role in soil $\mathrm{C}$ and $\mathrm{N}$ cycling [301].

\section{Current Challenges in Using Charcoal and Wood Ash as Adsorbents}

Charcoal and wood ash have been used as adsorbent materials some years ago and claimed to have advantages because of their low cost and suitable to remove heavy metals, organic and inorganic contaminants because of their potential physicochemical properties. Therefore, extensive studies have been carried out. However, there are challenges that limit the practical and large-scale use of charcoal and wood ash as adsorbents. First, in the field of $\mathrm{C}$ adsorbents, the stability of the charcoal and wood ash as adsorbents is not fully established. Nevertheless, high adsorption capacity and long-term cyclic operation are also important to ensure the economic viability of using them as adsorbents. For example, wood-based charcoal is cheaper than other adsorbents and can be sufficient adsorbent for some application, however, the characterisation of charcoal is necessary to evaluate its applicability as adsorbent as its depends on the raw material used. The initial capacity of a charcoal can be enhanced to become an activated charcoal after various treatments to enhance the surface adsorption affinity and selectivity towards targeted compounds. However, any modification comes with extra costs. Secondly, physical and 
chemical modification of charcoal and wood ash have been proposed mostly on laboratory scale. Large scale charcoal use is remains unclear. Moreover, laboratory scale use is mostly explorative. The practical optimisation for large-scale application of charcoal and wood ash as adsorbents are still lacking. This is because most adsorbents used especially for $\mathrm{NH}_{4}{ }^{+}$retention are used are limited laboratory-scale because of the limited availability of both charcoal and wood ash in nature.

\section{Conclusions}

The proper application and better understanding of the role of charcoal and wood ash as soil amendments could improve soil fertility, $\mathrm{N}$ availability, and crop productivity because of their specific physicochemical properties. The high specific surface area and internal porous structure of charcoal increase sorption of $\mathrm{NH}_{4}{ }^{+}$ions and retention of nitrate ions in soil water solution through entrapment inside the pores of charcoal, thus enhancing $\mathrm{N}$ availability for plant uptake. Even though adsorption of $\mathrm{NH}_{4}{ }^{+}$ions on wood ash exhibits intermediate adsorption capacity compare with charcoal, it has the potential to reduce nutrient loss besides being ideal for highly weathered acidic soil because of its acid neutralising properties. Sorption isotherms are practical approaches to elucidate retention of $\mathrm{N}$ with amendments such as charcoal and wood ash. This is important for understanding the movement of $\mathrm{N}$ in the environment. The major advantage of Langmuir equation over Freundlich equation is that an adsorption maximum can be related to several soil properties including, information on the reaction between soil and $\mathrm{N}$ fertilisers. Understanding adsorption-desorption distribution coefficient is essential because this approach provides insight on the mobility of a compound in the environment and its distribution between water, sludge, soil and sediment. BET theory is the extended approach to Langmuir isotherm that assumes multilayer adsorption of gas on the adsorbent's surface and all layers involved are in equilibrium. However, this approach is based on gas adsorption, thus the validity of monolayer capacity is problematic. Furthermore, on all surfaces, the monolayer is not the same. The use of charcoal and wood ash could be a better approach in adsorbing $\mathrm{N}$ to avoid leaching to maximise nutrient use efficiency. To this end, this review revealed the potential of charcoal and wood ash as soil amendments for agricultural systems because both amendments are highly available and accessible worldwide. In terms of agronomic efficiency, the application method is easy and does not require any special skills or techniques, thus the adoption of the amendments by farmers could be high. For economic and environmental efficiencies, using charcoal and wood ash in farming systems is low in cost because they have been transformed into soil conditioners that are able to improve soil productivity apart from their original materials having the potential of polluting the environment. Greenhouse and field trials are in progress to establish the effects of the combined use of charcoal, wood ash and urea on $\mathrm{N}$ sorption in soils.

Author Contributions: Writing—original draft preparation, conceptualisation, visualisation N.H.H.; validation, writing - review and editing, supervision, funding acquisition, O.H.A.; editing second draft L.O. and H.Y.C. All authors have read and agreed to the published version of the manuscript.

Funding: This research was funded by Ministry of Higher Education, Malaysia with grant number [ERGS/1/11/STWN/UPM/02/65].

Institutional Review Board Statement: Not applicable.

Informed Consent Statement: Not applicable.

Data Availability Statement: The data presented in this study are available within the article.

Acknowledgments: The authors acknowledge Ministry of Higher Education, Malaysia for financial assistance [ERGS/1/11/STWN/UPM/02/65] and Universiti Putra Malaysia for providing research facilities.

Conflicts of Interest: The authors declare that there are no conflict of interest regarding the publication of this paper. 


\section{References}

1. Godfray, H.C.J.; Beddington, J.R.; Crute, I.R.; Haddad, L.; Lawrence, D.; Muir, J.F.; Pretty, J.; Robinson, S.; Thomas, S.M.; Toulmin, C. Food Security: The Challenge of Feeding 9 Billion People. Science 2010, 327, 812-818. [CrossRef] [PubMed]

2. Lim, L.Y.; Lee, C.T.; Bong, C.P.C.; Lim, J.S.; Sarmidi, M.R.; Klemes, J.J. A Review on the Impacts of Compost on Soil Nitrogen Dynamics. Chem. Eng. Trans. 2018, 63, 349-354.

3. Liu, Q.; Liu, B.; Zhang, Y.; Hu, T.; Lin, Z.; Liu, G.; Wang, X.; Ma, J.; Wang, H.; Jin, H.; et al. Biochar Application as a Tool to Decrease Soil Nitrogen Losses [ $\mathrm{NH}_{3}$ Volatilization, $\mathrm{N}_{2} \mathrm{O}$ Emissions, and N Leaching] from Croplands: Options and Mitigation Strength in a Global Perpective. Glob. Chang. Biol. 2019, 25, 2077-2093. [CrossRef]

4. Naz, M.Y.; Sulaiman, S.A. Slow Release Coating Remedy for Nitrogen Loss from Conventional Urea: A Review. J. Control. Release 2016, 225, 109-120. [CrossRef] [PubMed]

5. Nweke, I.A. Effect of Land Use on Organic Matter Concentration of Aggregate Fractions of Fallow and Cultivated Soils. Indian J. Appl. Res. 2015, 5, 507-511.

6. Brady, N.C.; Weil, R.R. The Nature and Properties of Soils, 14th ed.; Pearson Education: Upper Saddle River, NJ, USA, 2008.

7. Liu, D.; Huang, Y.; Yan, H.; Jiang, Y.; Zhao, T.; An, S. Dynamics of Soil Nitrogen Fractions and Their Relationship with Soil Microbial Communities in Two Forest Species of Northern China. PLoS ONE 2018, 13, e0196567. [CrossRef]

8. Li, S.; Barreto, V.; Li, R.; Chen, G.; Hsieh, Y.P. Nitrogen Retention of Biochar Derived from Different Feedstocks at Variable Pyrolysis Temperatures. J. Anal. Appl. Pyrolysis 2018, 133, 136-146. [CrossRef]

9. Fan, M.X.; Mackenzie, A.F. Urea and Phosphate Interactions in Fertilizer Microsites: Ammonia Volatilization and pH Changes. Soil Sci. Soc. Am. J. 1993, 57, 839-845. [CrossRef]

10. Siva, K.B.; Aminuddin, H.; Husni, M.H.A.; Manas, A.R. Ammonia Volatilization from Urea as Affected by Tropical-Based Palm Oil Mill Effluent (Pome) and Peat. Commun. Soil Sci. Plant Anal. 1999, 30, 785-804. [CrossRef]

11. Theeba, M.; Husni, M.A.; Samsuri, A.W.; Robert, T.B.; Illani, Z.H. Nutrient Retention Capacity of Rice Husk Biocharcoal in Co-Composted Poultry Manure. J. Trop. Agric. Food. Sci. 2016, 44, 197-209.

12. Ariyaratne, R.M. Integrated Plant Nutrition Systems (IPNS) Training Manual (Sri Lanka); The Fertilizer Advisory, Development Information Network for Asia and the Pacific (FADINAP): Bangkok, Thailand, 2000; p. 140.

13. Tiessen, H.; Cuevas, E.; Chacon, P. The Role of Soil Organic Matter in Sustaining Soil Fertility. Nature 1994, 371, 783-785. [CrossRef]

14. Fearnside, P.M. Global Warming and Tropical Land-Use Change: Greenhouse Gas Emissions from Biomass Burning, Decomposition and Soils in Forest Conversion, Shifting Cultivation and Secondary Vegetation. Clim. Chang. 2000, 46, 115-158. [CrossRef]

15. Gul, S.; Whalen, J.K. Biochemical Cycling of Nitrogen and Phosphorus in Biochar-Amended Soils. Soil Biol. Biochem. 2016, 103, 1-15. [CrossRef]

16. Brewer, C.E.; Brown, R.C. Biochar. In Comprehensive Renewable Energy; Sayigh, A., Ed.; Elsevier: Amsterdam, The Netherlands; Oxford, UK, 2012; pp. 357-384.

17. Lehmann, J. Biochar for Environmental Management: Science and Technology; Lehmann, J., Joseph, S., Eds.; Earthscan: London, UK; Washington, DC, USA, 2009.

18. Kocsis, T.; Biró, B.; Ulmer, Á.; Szántó, M.; Kotroczó, Z. Time-Lapse Effect of Ancient Plant Coal Biochar on Some Soil Agrochemical Parameters and Soil Characteristics. Environ. Sci. Pollut. Res. 2018, 25, 990-999. [CrossRef] [PubMed]

19. Yu, X.-Y.; Ying, G.-G.; Kookana, R.S. Sorption and Desorption Behaviors of Diuron in Soils Amended with Charcoal. J. Agric. Food Chem. 2006, 54, 8545-8550. [CrossRef] [PubMed]

20. Patel, H. Charcoal as an Adsorbent for Textile Wastewater Treatment. Sep. Sci. Technol. 2018, 53, 2797-2812. [CrossRef]

21. Zackrisson, O.; Nilsson, M.-C.; Wardle, D.A. Key Ecological Function of Charcoal from Wildfire in the Boreal Forest Key Ecological Function of Charcoal from Wildfire in the Boreal Forest. Oikos 1996, 77, 10-19. [CrossRef]

22. Pluchon, N.; Gundale, M.J.; Nilsson, M.-C.; Kardol, P.; Wardle, D.A. Stimulation of Boreal Tree Seedling Growth by Wood-Derived Charcoal: Effects of Charcoal Properties, Seedling Species and Soil Fertility. Funct. Ecol. 2014, 28, 766-775. [CrossRef]

23. Mohammad-khah, A.; Ansari, R. Activated Charcoal: Preparation, Characterization and Applications: A Review Article. Int. J. ChemTech Res. 2009, 1, 859-864.

24. Masek, O. Biochar Production Technologies. In Biochar for Environmental Management: Science, Technology and Implementation, 2nd Ed.; Chapter: Biochar Production Technology; Johannes, L., Stephen, J., Eds.; Routledge: Oxfordshire, UK, 2014.

25. Demirbas, A.; Ahmad, W.; Alamoudi, R.; Sheikh, M. Sustainable Charcoal Production from Biomass. Energy Sources Part A Recover. Util. Environ. Eff. 2016, 38, 1882-1889. [CrossRef]

26. Zhang, Z.H.; Wang, W.X.; Yang, X.Y.; Hu, Q.X.; Li, Y.F. Preparation of 4A Zeolite from Coal Gangue through a Alkali Fusion Method. China Surfactant Deterg Cosmet 2008, 5, 294-297.

27. Kookana, R.S.; Sarmah, A.K.; Zwieten, L.V.; Krull, E.; Singh, B. Biochar Application to Soil: Agronomic and Environmental Benefits and Unintendedsystem in California. Agric. Ecosyst. Environ. 2011, 191, 17-26.

28. Jindo, K.; Mizumoto, H.; Sawada, Y.; Sanchez-Monedero, M.A.; Sonoki, T. Physical and Chemical Characterization of Biochars Derived from Different Agricultural Residues. Biogeosciences 2014, 11, 6613. [CrossRef]

29. DeLuca, T.H.; MacKenzie, M.D.; Gundale, M.J. Biochar Effects on Soil Nutrient Transformations. In Biochar for Environmental Management Science and Technology; Lehmann, J., Joseph, S., Eds.; Earthscan: London, UK, 2009; pp. 251-270. 
30. Glaser, B.; Lehmann, J.; Zech, W. Ameliorating Physical and Chemical Properties of Highly Weathered Soils in the Tropics with Charcoal-A Review. Biol. Fertil. Soils 2002, 35, 219-230. [CrossRef]

31. Kalyani, P.; Ariharaputhiran, A.; Darchen, A. Activated Carbon from Grass-A Green Alternative Catalyst Support for Water Electrolysis. Int. J. Hydrog. Energy 2013, 38, 10364-10372. [CrossRef]

32. Van Laer, T.; De Smedt, P.; Ronsse, F.; Ruysschaert, G.; Boeckx, P.; Verstraete, W.; Lavrysen, L.J. Legal Constraints and Opportunities for Biochar: A Case Analysis of EU Law. Gcb Bioenergy 2015, 7, 14-24. [CrossRef]

33. Demeyer, A.; Nkana, J.V.; Verloo, M.G. Characteristics of Wood Ash and Influence on Soil Properties and Nutrient Uptake: An Overview. Bioresour. Technol. 2001, 77, 287-295. [CrossRef]

34. Nweke, I.A.; Mbah, C.N.; Oweremadu, E.O.; Dambaba, N.; Orji, E.C.; Ekesiobi, A.I.; Nnabuife, E.L.C. Soil pH, Available P of an Ultisol and Castor Performance as Influenced by Contrasting Tillage Methods and Wood Ash. Afr. J. Agric. Res. 2017, 12, 606-616. [CrossRef]

35. Quilliam, R.S.; Glanville, H.C.; Wade, S.C.; Jones, D.L. Life in the 'Charosphere' Does Biochar in Agricultural Soil Provide a Significant Habitat for Microorganisms? Soil Biol. Biochem. 2013, 65, 287-293. [CrossRef]

36. Quilliam, R.S.; DeLuca, T.H.; Jones, D.L. Biochar Application Rate Reduces Root Nodulation in Clover but Increases Nitrogenase Activity in Nodules. Plant Soil 2013, 366, 83-92. [CrossRef]

37. Kilpimaa, S.; Kuokannen, T.; Lassi, U. Characterization and Utilization Potential of Wood Ash Form Combustion Process and Carbon Residue from Gasification Process. BioResources 2013, 8, 1011-1027. [CrossRef]

38. Scheepers, G.P.; Du Toit, B. Potential Use of Wood Ash in South African Forestry: A Review. South. For. A J. For. Sci. 2016, 78, 255-266. [CrossRef]

39. Anda, M.; Shamshuddin, J.; Fauziah, C.I.; Omar, S.S. Mineralogy and Factors Controlling Charge Development of Three Oxisols Developed from Different Parent Materials. Geoderma 2008, 143, 153-167. [CrossRef]

40. Shamshuddin, J.; Daud, N.W. Classification and Management of Highly Weathered Soils in Malaysia for Production of Plantation Crops. Princ. Appl. Assess. Soil Sci. 2011, 2011, 75-86.

41. Kidd, P.S.; Proctor, J. Why Plants Grow Poorly on Very Acid Soils: Are Ecologists Missing the Obvious? J. Exp. Bot. 2001, 52, 791-799. [CrossRef] [PubMed]

42. Zech, W.; Senesi, N.; Guggenberger, G.; Kaiser, K.; Lehmann, J.; Miano, T.M.; Miltner, A.; Schroth, G. Factors Controlling Humification and Mineralization of Soil Organic Matter in the Tropics. Geoderma 1997, 79, 117-161. [CrossRef]

43. Brown, T.T.; Koenig, R.T.; Huggins, D.R.; Harsh, J.B.; Rossi, R.E. Lime Effects on Soil Acidity, Crop Yield, and Aluminum Chemistry in Direct-Seeded Cropping Systems. Soil Sci. Soc. Am. J. 2008, 72, 634-640. [CrossRef]

44. Shamshuddin, J.; Fauziah, C.I.; Bell, L.C. Soil Solution Properties and Yield of Corn and Groundnut Grown on Ultisols as Affected by Dolomitic Limestone and Gypsum Applications. Malays. J. Soil Sci. 2009, 13, 1-12.

45. Ohno, T.; Amirbahman, A. Phosphorus Availability in Boreal Forest Soils: A Geochemical and Nutrient Uptake Modeling Approach. Geoderma 2010, 155, 46-54. [CrossRef]

46. Ohno, T.; Fernandez, I.J.; Hiradate, S.; Sherman, J.F. Effects of Soil Acidification and Forest Type on Water Soluble Soil Organic Matter Properties. Geoderma 2007, 140, 176-187. [CrossRef]

47. Harter, R.D. Acid Soils of the Tropics. ECHO Technical Note, ECHO. 2007. Volume 11. Available online: http://courses.umass. edu/psoil370/Syllabus-files/Acid_Soils_of_the_Tropics.pdf (accessed on 1 May 2021).

48. Masclaux-Daubresse, C.; Daniel-Vedele, F.; Dechorgnat, J.; Chardon, F.; Gaufichon, L.; Suzuki, A. Nitrogen Uptake, Assimilation and Remobilization in Plants: Challenges for Sustainable and Productive Agriculture. Ann. Bot. 2010, 105, 1141-1157. [CrossRef] [PubMed]

49. Follett, R.F. Transformation and Transport Processes of Nitrogen in Agricultural Systems. Nitrogen Environ. 2008, 2008, 19-50. [CrossRef]

50. Grain Research and Development Corporation (GRDC). Maximising Nitrogen Availability to Crops. Plant Available Nitrogen [Fact Sheet]. Australian Government. 2013. Available online: https://grdc.com.au/resources-and-publications/all-publications / factsheets / 2013/08/grdc-fs-plantavailablenitrogen (accessed on 1 May 2021).

51. Latifah, O.; Ahmed, O.H.; Majid, N.M.A. Enhancing Nitrogen Availability from Urea Using Clinoptilolite Zeolite. Geoderma 2017, 306, 152-159. [CrossRef]

52. Brady, N.C.; Weil, R.R.; Brady, N.C. Elements of the Nature and Properties of Soils; Pearson Educational International: Upper Saddle River, NJ, USA, 2010.

53. Korhonen, J.F.J.; Pihlatie, M.; Pumpanen, J.; Aaltonen, H.; Hari, P.; Levula, J.; Ilvesniemi, H. Nitrogen Balance of a Boreal Scots Pine Forest. Biogeosciences 2013, 10, 1083-1095. [CrossRef]

54. Sainju, U.M.; Caesar-Tonthat, T.; Lenssen, A.W.; Evans, R.G.; Kolberg, R. Tillage and Cropping Sequence Impacts on Nitrogen Cycling in Dryland Farming in Eastern Montana. Soil Tillage Res. 2009, 103, 332-341. [CrossRef]

55. Zhang, J.; Song, C.; Wenyan, Y. Tillage Effects on Soil Carbon Fractions in the Sanjiang Plain, Northeast China. Soil Tillage Res. 2007, 93, 102-108. [CrossRef]

56. Sainju, U.M.; Lenssen, A.W.; Caesar-TonThat, T.; Jabro, J.D.; Lartey, R.T.; Evans, R.G.; Allen, B.L. Dryland Soil Nitrogen Cycling Influenced by Tillage, Crop Rotation, and Cultural Practice. Nutr. Cycl. Agroecosystems 2012, 93, 309-322. [CrossRef]

57. Sainju, U.M.; Lenssen, A.W.; Allen, B.L.; Stevens, W.B.; Jabro, J.D. Nitrogen Balance in Response to Dryland Crop Rotations and Cultural Practices. Agric. Ecosyst. Environ. 2016, 233, 25-32. [CrossRef] 
58. Kelley, K.R.; Stevenson, F.J. Forms and Nature of Organic N in Soil. In Nitrogen Economy in Tropical Soils; Springer: Dordrecht, The Netherlands, 1995; pp. 1-11.

59. Amelung, W.; Zhang, X. Determination of Amino Acid Enantiomers in Soils. Soil Biol. Biochem. 2001, 33, 553-562. [CrossRef]

60. Nannipieri, P.; Eldor, P. The Chemical and Functional Characterization of Soil N and Its Biotic Components. Soil Biol. Biochem. 2009, 41, 2357-2369. [CrossRef]

61. Schulten, H.R.; Schnitzer, M. The Chemistry of Soil Organic Nitrogen: A Review. Biol. Fertil. Soils 1997, 26, 1-15. [CrossRef]

62. Schulten, H.R.; Leinweber, P.; Schnitzer, M. Analytical Pyrolysis and Computer Modelling of Humic and Soil Particles. In Structure and Surface Reactions of Soil Particles; John Wiley and Sons Ltd.: Hoboken, NJ, USA, 1998; pp. 281-324.

63. Giese, A.C. Cell Physiology; Saunders Co.: Philadelphia, PA, USA, 1979.

64. Stevenson, F.J. Humus Chemistry: Genesis, Composition, Reactions; John Wiley Sons: Hoboken, NJ, USA, $1994 ;$ pp. 59-95.

65. Parsons, J.W. Chemistry and Distribution of Amino Sugars in Soils and Soil Organisms. Soil Biochem. 1981, 5, 197-227.

66. Schmidt, B.H.; Kalbitz, K.; Braun, S.; Fuß, R.; McDowell, W.H.; Matzner, E. Microbial Immobilization and Mineralization of Dissolved Organic Nitrogen from Forest Floors. Soil Biol. Biochem. 2011, 43, 1742-1745. [CrossRef]

67. Miller, A.J.; Cramer, M.D. Root Nitrogen Acquisition and Assimilation. Plant Soil 2005, 274, 1-36. [CrossRef]

68. Ashton, I.W.; Miller, A.E.; Bowman, W.D.; Suding, K.N. Niche Complementarity Due to Plasticity in Resource Use: Plant Partitioning of Chemical N Forms. Ecology 2010, 91, 3252-3260. [CrossRef] [PubMed]

69. Walworth, J. Nitrogen in the Soil and the Environment. 2013. Available online: https://repository.arizona.edu/bitstream/ handle/10150/267773/az1591-2013.pdf?sequence=1 (accessed on 1 May 2021).

70. Vigil, M.F.; Kissel, D.E. Equations for Estimating the Amount of Nitrogen Mineralized from Crop Residues. Soil Sci. Soc. Am. J. 1991, 55, 757-761. [CrossRef]

71. Keuper, F.; Dorrepaal, E.; Van Bodegom, P.M.; Van Logtestijn, R.; Venhuizen, G.; Van Hal, J.; Aerts, R. Experimentally Increased Nutrient Availability at The Permafrost Thaw Front Selectively Enhances Biomass Production of Deep-Rooting Subarctic Peatland Species. Glob. Chang. Biol. 2017, 23, 4257-4266. [CrossRef] [PubMed]

72. Hawkins, B.J.; Robbins, S. PH Affects Ammonium, Nitrate and Proton Fluxes in the Apical Region of Conifer and Soybean Roots. Physiol. Plant. 2010, 138, 238-247. [CrossRef] [PubMed]

73. Xu, G.; Fan, X.; Miller, A.J. Plant Nitrogen Assimilation and Use Efficiency. Annu. Rev. Plant Biol. 2012, 63, 153-182. [CrossRef] [PubMed]

74. Strahm, B.D.; Harrison, R.B. Nitrate Sorption in a Variable-Charge Forest Soil of the Pacific Northwest. Soil Sci. 2006, 171, 313-321. [CrossRef]

75. Marschner, P. Marschner's Mineral Nutrition of Higher Plants, 3th ed.; Academic Press: London, UK; Waltham, MA, USA, 2012; pp. 135-151.

76. Britto, D.T.; Kronzucker, H.J. $\mathrm{NH}_{4}{ }^{+}$Toxicity in Higher Plants: A Critical Review. J. Plant Physiol. 2002, 159, 567-584. [CrossRef]

77. Dodds, W.K.; Whiles, M.R. Nitrogen, Sulfur, Phosphorus, and Other Nutrients. Freshw. Ecol. 2010, 2010, 345-373. [CrossRef]

78. Gupta, P.K. A Handbook of Soil, Fertilizer and Manure; Agrobios: Chopasni Road, Jodhpur, India, 2003.

79. Hirel, B.; Tétu, T.; Lea, P.J.; Dubois, F. Improving Nitrogen Use Efficiency in Crops for Sustainable Agriculture. Sustainability 2011, 3, 1452-1485. [CrossRef]

80. Omar, L. Development, Beneficial Effects, and Economic Viability of Rice Straw and Paddy Husk Composts in Combination with Clinoptilolite Zeolite. Doctoral Thesis, Universiti Putra Malaysia, Seri Kembangan, Malaysia, 2016.

81. Havlin, J.L.; Beaton, J.D.; Tisdale, S.L.; Nelson, W.L. Soil Fertility and Fertilizers: An Introduction to Nutrient Management, 17th ed.; Prientice Hall: Hoboken, NJ, USA, 2005.

82. Guo, J.H.; Liu, X.J.; Zhang, Y.; Shen, J.L.; Han, W.X.; Zhang, W.F.; Zhang, F.S. Significant Acidification in Major Chinese Croplands. Science 2010, 327, 1008-1010. [CrossRef] [PubMed]

83. Kusano, M.; Fukushima, A.; Redestig, H.; Saito, K. Metabolomic Approaches toward Understanding Nitrogen Metabolism in Plants. J. Exp. Bot. 2011, 62, 1439-1453. [CrossRef]

84. Wang, M.; Shen, Q.; Xu, G.; Guo, S. New Insight into the Strategy for Nitrogen Metabolism in Plant Cells. Int. Rev. Cell Mol. Boil. 2014, 310, 1-37.

85. Coruzzi, G.; Bush, D.R. Nitrogen and Carbon Nutrient and Metabolite Signaling in Plants. Plant Physiol. 2001, 125, 61-64. [CrossRef] [PubMed]

86. Miller, A.J.; Fan, X.; Orsel, M.; Smith, S.J.; Wells, D.M. Nitrate Transport and Signalling. J. Exp. Bot. 2007, 58, 2297-2306. [CrossRef] [PubMed]

87. Schachtman, D.P.; Shin, R. Nutrient Sensing and Signaling: NPKS. Annu. Rev. Plant Biol. 2007, 58, 47-69. [CrossRef] [PubMed]

88. Krouk, G.; Crawford, N.M.; Coruzzi, G.M.; Tsay, Y.F. Nitrate Signaling: Adaptation to Fluctuating Environments. Curr. Opin. Plant Biol. 2010, 13, 265-272. [CrossRef] [PubMed]

89. Zhang, H.; Forde, B.G. An Arabidopsis MADS Box Gene that Controls Nutrient-Induced Changes in Root Architecture. Science 1998, 279, 407-409. [CrossRef] [PubMed]

90. Walch-Liu, P.; Neumann, G.; Bangerth, F.; Engels, C. Rapid Effects of Nitrogen Form on Leaf Morphogenesis in Tobacco. J. Exp. Bot 2000, 51, 227-237. [CrossRef] [PubMed]

91. Stitt, M.; Müller, C.; Matt, P.; Gibon, Y.; Carillo, P.; Morcuende, R.; Scheible, W.R.; Krapp, A. Steps towards an Integrated View of Nitrogen Metabolism. J. Exp. Bot 2002, 53, 959-970. [CrossRef] 
92. Alboresi, A.; Gestin, C.; Leydecker, M.T.; Bedu, M.; Meyer, C.; Truong, H.N. Nitrate, a Signal Relieving Seed Dormancy in Arabidopsis. Plant Cell Environ. 2005, 28, 500-512. [CrossRef] [PubMed]

93. Ahmed, O.H.; Ab Majid, N.M. Towards Efficient Utilization of Nitrogen Based Fertilizers; Universiti Putra Malaysia Press: Serdang, Selangor, Malaysia, 2014.

94. Scarsbrook, C.E. Nitrogen Availability. Soil Nitrogen 1965, 10, 481-502.

95. Gouveia, G.A.; Eudoxie, G.D. Distribution of Fertilizer N among fixed Ammonium Fractions as Affected by Moisture and Fertilizer Source and Rate. Biol. Fertil. Soils 2007, 44, 9-18. [CrossRef]

96. Gonçalves, J.D.M.; Carlyle, J.C. Modelling the Influence of Moisture and Temperature on Net Nitrogen Mineralization in a Forested Sandy Soil. Soil Biol. Biochem. 1994, 26, 1557-1564. [CrossRef]

97. Sugihara, S.; Funakawa, S.; Kilasara, M.; Kosaki, T. Dynamics of Microbial Biomass Nitrogen in Relation to Plant Nitrogen Uptake during the Crop Growth Period in a Dry Tropical Cropland in Tanzania. Soil Sci. Plant Nutr. 2010, 56, 105-114. [CrossRef]

98. Abera, G.; Wolde-meskel, E.; Beyene, S.; Bakken, L.R. Nitrogen Mineralization Dynamics under Different Moisture Regimes in Tropical Soils. Int. J. Soil Sci. 2012, 7, 132. [CrossRef]

99. Baulch, H.M. Asking the Right Questions about Nutrient Control in Aquatic Ecosystems. Environ. Sci. Technol. 2013, 47, 1188-1189. [CrossRef] [PubMed]

100. Robertson, G.P.; Groffman, P.M. Nitrogen Transformations. In Soil Microbiology, Ecology and Biochemistry; Academic Press: Cambridge, MA, USA, 2007; pp. 341-364.

101. Myrold, D.D.; Bottomley, P.J. Nitrogen Mineralization and Immobilization. Nitrogen Agric. Syst. 2008, 49, $157-172$.

102. Liu, D.; Keiblinger, K.M.; Leitner, S.; Mentler, A.; Zechmeister-Boltenstern, S. Is There a Convergence of Deciduous Leaf Litter Stoichiometry, Biochemistry and Microbial Population during Decay? Geoderma 2016, 272, 93-100. [CrossRef]

103. Ameloot, N.; Sleutel, S.; Das, K.C.; Kanagaratnam, J.; De Neve, S. Biochar Amendment to Soils with Contrasting Organic Matter Level: Effects on N Mineralization and Biological Soil Properties. Gcb Bioenergy 2015, 7, 135-144. [CrossRef]

104. Rousk, K.; Michelsen, A.; Rousk, J. Microbial Control of Soil Organic Matter Mineralization Responses to Labile Carbon in Subarctic Climate Change Treatments. Glob. Chang. Biol. 2016, 22, 4150-4161. [CrossRef] [PubMed]

105. Clough, T.J.; Condron, L.M.; Kammann, C.; Müller, C. A Review of Biochar and Soil Nitrogen Dynamics. Agronomy 2013, 3 , 275-293. [CrossRef]

106. Prosser, J.I.; Embley, T.M.; Webster, G. The Influence of Selection Pressures on Species Diversity, Functional Gene Diversity and Activity of Ammonia-Oxidizing Bacteria. In 'Genes in the Environment'. The Fifteenth Special Symposium of the British Ecological Society, Oxford, UK, 17-19 September 2001; Blackwell Publishing: Hoboken, NJ, USA, 2003; pp. 187-202.

107. Dobrovol'skaya, T.G.; Zvyagintsev, D.G.; Chernov, I.Y.; Golovchenko, A.V.; Zenova, G.M.; Lysak, L.V.; Manucharova, N.A.; Marfenina, O.E.; Polysnskaya, L.M.; Stepanov, A.L.; et al. The Role of Microorganisms in the Ecological Functions of Soils. Eurasian Soil Sci. 2015, 48, 959-967. [CrossRef]

108. Berg, P.; Rosswall, T. Abiotic Factors Regulating Nitrification in a Swedish Arable Soil. Biol. Fertil. Soils 1989, 8, 247-254. [CrossRef]

109. Macura, J.; Stotzky, G. Effect of Montmorillonite and Kaolinite on Nitrification in Soil. Folia Microbiol. 1980, 25, 90-105. [CrossRef] [PubMed]

110. Castaldi, S.; Riondino, M.; Baronti, S.; Esposito, F.R.; Marzaioli, R.; Rutigliano, F.A. Impact of Biochar Application to a Mediterranean Wheat Crop on Soil Microbial Activity and Greenhouse Gas Fluxes. Chemosphere 2012, 85, 1464-1471. [CrossRef]

111. Ball, P.N.; MacKenzie, M.D.; DeLuca, T.H.; Holben, W.E. Wildfire and Charcoal Enhance Nitrification and Ammonium-Oxidizing Bacterial Abundance in Dry Montane Forest Soils. J. Environ.Qual. 2010, 39, 1243-1253. [CrossRef]

112. Cheng, Y.; Cai, Z.C.; Chang, S.X.; Wang, J.; Zhang, J.B. Wheat Straw and Its Biochar Have Contrasting Effects on Inorganic N Retention and N2O Production in a Cultivated Black Chernozem. Biol. Fertil. Soils 2012, 48, 941-946. [CrossRef]

113. Klemedtsson, L.; Svensson, B.H.; Rosswall, T. Relationships between Soil Moisture Content and Nitrous Oxide Production during Nitrification and Denitrification. Biol. Fertil. Soils 1988, 6, 106-111. [CrossRef]

114. Firestone, M.K.; Davidson, E.A. Microbiological Basis of $\mathrm{NO}$ and $\mathrm{N}_{2} \mathrm{O}$ Production and Consumption in Soil. Exch. Trace Gases Terr Ecosyst. Atmos. 1988, 47, 7-21.

115. Mosier, A.R. Exchange of Gaseous Nitrogen Compounds between Agricultural SYSTEMS and the atmosphere. Plant Soil 2001, 228, 17-27. [CrossRef]

116. Bornø, M.L.; Rønn, R.; Ekelund, F. Is Wood Ash Amendment a Suitable Mitigation Strategy for N2O Emissions from Soil? Sci. Total Environ. 2020, 713, 136581. [CrossRef] [PubMed]

117. Liu, L.; Zhang, X.; Xu, W.; Liu, X.; Li, Y.; Wei, J.; Wang, Z.; Lu, X. Ammonia Volatilization as the Major Nitrogen Loss Pathway in Dryland Agro-Ecosystems. Environ. Pollut. 2020, 265, 114-862. [CrossRef] [PubMed]

118. Galloway, J.N.; Townsend, A.R.; Erisman, J.W.; Bekunda, M.; Cai, Z.; Freney, J.R.; Martinelli, L.A.; Seitzinger, S.P.; Sutton, M.A. Transformation of the Nitrogen Cycle: Recent Trends, Questions, and Potential Solutions. Science 2008, 320, 889-892. [CrossRef] [PubMed]

119. Gu, B.; Ge, Y.; Ren, Y.; Xu, B.; Luo, W.; Jiang, H.; Chang, J. Atmospheric Reactive Nitrogen in China: Sources, Recent Trends, and Damage Costs. Environ. Sci. Technol. 2012, 46, 9420-9427. [CrossRef] [PubMed]

120. Harrison, R.; Webb, J. A Review of the Effect of N Fertilizer Type on Gaseous Emissions. In Advances in Agronomy; Elsevier: Amsterdam, The Netherlands, 2001. 
121. Rochette, P.; Angers, D.A.; Chantigny, M.H.; Gasser, M.O.; MacDonald, J.D.; Pelster, D.E.; Bertrand, N. NH 3 Volatilization, Soil Concentration and Soil pH Following Subsurface Banding of Urea at Increasing Rates. Can. J. Soil Sci. 2013, 93, 261-268. [CrossRef]

122. Peng, X.; Maharjan, B.; Yu, C.; Su, A.; Jin, V.; Ferguson, R.B. A Laboratory Evaluation of Ammonia Volatilization and Nitrate Leaching Following Nitrogen Fertilizer Application on a Coarse-Textured Soil. Agron. J. 2015, 107, 871-879. [CrossRef]

123. Stevenson, F.J.; Cole, M.A. Cycles of Soil: Carbon, Nitrogen, Phosphorus, Sulfur, Micronutrients; John Wiley Sons: New York, NY, USA, 1999.

124. Liyanage, L.R.M.C.; Jayakody, A.N.; Gunaratne, G.P. Ammonia Volatilization from Frequently Applied Fertilizers for the Low-Country Tea Growing Soils of Sri Lanka. Trop. Agric. Res. 2014, 26, 48-61. [CrossRef]

125. Guimarães, G.G.; Mulvaney, R.L.; Cantarutti, R.B.; Teixeira, B.C.; Vergütz, L. Value of Copper, Zinc, and Oxidized Charcoal for Increasing Forage Efficiency of Urea N Uptake. Agric. Ecosyst. Environ. 2016, 224, 157-165. [CrossRef]

126. Paiva, D.M.D.; Cantarutti, R.B.; Guimarães, G.G.F.; Silva, I.R.D. Urea Coated with Oxidized Charcoal Reduces Ammonia Volatilization. Rev. Bras. De Ciênc. Do Solo 2012, 36, 1221-1230. [CrossRef]

127. Puga, A.P.; Melo, L.C.A.; De Abreu, C.A.; Coscione, A.R.; Paz-Ferreiro, J. Leaching and Fractionation of Heavy Metals in Mining Soils Amended with Biochar. Soil Tillage Res. 2016, 164, 25-33. [CrossRef]

128. Jury, W.A.; Nielsen, D.R. Nitrate Transport and Leaching Mechanisms. In Developments in Agricultural and Managed Forest Ecology; Elsevier: Amsterdam, The Netherlands, 1989; Volume 21, pp. 139-157.

129. Di, H.J.; Cameron, K.C. Nitrate Leaching in Temperate Agroecosystems: Sources, Factors and Mitigating Strategies. Nutr. Cycl. Agroecosyst. 2002, 64, 237-256. [CrossRef]

130. Addiscott, T.M. Measuring and Modelling Nitrogen Leaching: Parallel Problems. In Progress in Nitrogen Cycling Studies; Springer: Dordrecht, The Netherlands, 1996; pp. 665-670.

131. Meisinger, J.J.; Delgado, J.A. Principles for Managing Nitrogen Leaching. J. Soil Water Conserve. 2002, 57, 485-498.

132. O'Leary, M.; Rehm, G.; Schmitt, M. Understanding Nitrogen in Soils; Project no. 89-EWQI-1-9180; U.S. Department of Agriculture, Extension Service: Minneapolis, MN, USA, 2002.

133. Foster, G.R.; Young, R.A.; Römkens, M.J.M.; Onstad, C.A. Processes of Soil Erosion by Water. Soil Eros. Crop Product. 1985, 1985, 137-162. [CrossRef]

134. Lehman, O.R.; Ahuja, L.R. Interflow of Water and Tracer Chemical on Sloping Field Plots with Exposed Seepage Faces. J. Hydrol. 1985, 76, 307-317. [CrossRef]

135. Lassaletta, L.; Billen, G.; Grizzetti, B.; Anglade, J.; Garnier, J. 50 Year Trends in Nitrogen Use Efficiency of World Cropping Systems: The Relationship between Yield and Nitrogen Input to Cropland. Environ. Res. Lett. 2014, 9, 105011. [CrossRef]

136. Good, A.G.; Shrawat, A.K.; Muench, D.G. Can Less Yield More? Is Reducing Nutrient Input into the Environment Compatible with Maintaining Crop Production? Trends Plant Sci. 2004, 9, 597-605. [CrossRef]

137. Nielsen, R.L. N Loss Mechanisms and Nitrogen Use Efficiency. In Purdue Nitrogen Management Workshops; Purdue University: West Lafayette, IN, USA, 2006; pp. 1-5.

138. Kant, S.; Bi, Y.M.; Rothstein, S.J. Understanding Plant Response to Nitrogen Limitation for the Improvement of Crop Nitrogen Use Efficiency. J. Exp. Bot. 2011, 62, 1499-1509. [CrossRef]

139. Lin, H.C.; Huber, J.A.; Gerl, G.; Hülsbergen, K.J. Nitrogen Balances and Nitrogen-Use Efficiency of Different Organic and Conventional Farming Systems. Nutr. Cycl. Agroecosystems 2016, 105, 1-23. [CrossRef]

140. Andrews, M.; Lea, P.J.; Raven, J.A.; Lindsey, K. Can Genetic Manipulation of Plant Nitrogen Assimilation Enzymes Result in Increased Crop Yield and Greater N-Use Efficiency? An assessment. Ann. Appl. Biol. 2004, 145, 25-40. [CrossRef]

141. Andrews, M.; Raven, J.A.; Lea, P.J.; Sprent, J.I. A Role for Shoot Protein in Shoot-Root Dry Matter Allocation in Higher Plants. Ann. Bot. 2006, 97, 3-10. [CrossRef] [PubMed]

142. Keating, B.A.; Carberry, P.S.; Bindraban, P.S.; Asseng, S.; Meinke, H.; Dixon, J. Eco-Efficient Agriculture: Concepts, Challenges, and Opportunities. Crop Sci. 2010, 50, S-109. [CrossRef]

143. Spiertz, J.H.J. Nitrogen, Sustainable Agriculture and Food Security: A review. In Sustainable Agriculture; Lichtfouse E., Navarrete M., Debaeke P., Véronique S., Alberola C., Eds.; Springer: Dordrecht, The Netherlands, 2009; Volume 2019, pp. 635-651. [CrossRef]

144. Zhang, F.; Cui, Z.; Fan, M.; Zhang, W.; Chen, X.; Jiang, R. Integrated Soil-Crop System Management: Reducing Environmental Risk While Increasing Crop Productivity and Improving Nutrient Use Efficiency in China. J. Environ. Qual. 2011, 40, 1051-1057. [CrossRef] [PubMed]

145. Kuosmanen, N. Estimating Stocks and Flows of Nitrogen: Application of Dynamic Nutrient Balance to European Agriculture. Ecol. Econ. 2014, 108, 68-78. [CrossRef]

146. Al-Naggar, A.M.M.; Shabana, R.; Abd El-Aleem, M.M.; El-Rashidy, Z. Selection Criteria for High Nitrogen Use Efficiency in Wheat [Triticum aestivum L.] Parents and their F1 and F2 Progenies. J. Agric. Ecol. Res. Int. 2016, 5, 1-15. [CrossRef]

147. Zhang, X.; Davidson, E.A.; Mauzerall, D.L.; Searchinger, T.D.; Dumas, P.; Shen, Y. Managing Nitrogen for Sustainable Development. Nature 2015, 528, 51-59. [CrossRef]

148. Bouwman, A.F.; Beusen, A.H.W.; Lassaletta, L.; Van Apeldoorn, D.F.; Van Grinsven, H.J.M.; Zhang, J. Lessons from Temporal and Spatial Patterns in Global Use of N and P Fertilizer on Cropland. Sci. Rep. 2017, 7, 1-11. [CrossRef] [PubMed]

149. Schenk, M.K. Nutrient Efficiency of Vegetable Crops. Acta Horticulturae 2006, 700, 21-34. [CrossRef] 
150. Burns, L.G. Assessing N Fertilizer Requirements and the Reliability of Different Recommendation Systems. Acta Hortic. 2006, 35-48. [CrossRef]

151. Han, M.; Okamoto, M.; Beatty, P.H.; Rothstein, S.J.; Good, A.G. The Genetics of Nitrogen Use Efficiency in Crop Plants. Annu. Rev. Genet. 2015, 49, 269-289. [CrossRef] [PubMed]

152. Agostini, F.; Tei, F.; Silgram, M.; Farneselli, M.; Benincasa, P.; Aller, M.F. Decreasing Nitrate Leaching in Vegetable Crops with Better N Management. In Genetic Engineering, Biofertilisation, Soil Quality and Organic Farming; Springer Science\&Business Media: Berlin/Heidelberg, Germany, 2010; pp. 147-200.

153. Darnhofer, I.; Bellon, S.; Dedieu, B.; Milestad, R. Adaptiveness to Enhance the Sustainability of Farming Systems. A Review. Agron. Sustain. Dev. 2010, 30, 545-555. [CrossRef]

154. Schaap, B.F.; Blom-Zandstra, M.; Hermans, C.M.; Meerburg, B.G.; Verhagen, J. Impact Changes of Climatic Extremes on Arable Farming in the North of the Netherlands. Reg. Environ. Chang. 2011, 11, 731-741. [CrossRef]

155. Cassman, K.G.; Dobermann, A.; Walters, D.T. Agroecosystems, Nitrogen-Use Efficiency, and Nitrogen Management. AMBIO A J. Hum. Environ. 2002, 31, 132-140. [CrossRef] [PubMed]

156. Lützow, M.V.; Kögel-Knabner, I.; Ekschmitt, K.; Matzner, E.; Guggenberger, G.; Marschner, B.; Flessa, H. Stabilization of Organic Matter in Temperate Soils: Mechanisms and Their Relevance under Different Soil Conditions-A Review. Eur. J. Soil Sci. 2006, 57, 426-445. [CrossRef]

157. Kleber, M. What is Recalcitrant Soil Organic Matter? Environ. Chem. 2010, 7, 320-332. [CrossRef]

158. Raworth, K. A Safe and Just Space for Humanity: Can We Live within the Doughnut? Oxfam: Nairobi, Kenya, 2012.

159. Buss, S.R.; Herbert, A.W.; Morgan, P.; Thornton, S.F.; Smith, J.W.N. A Review of Ammonium Attenuation in Soil and Groundwater. Q. J. Eng. Geol. Hydrogeol. 2004, 37, 347-359. [CrossRef]

160. Sharifnia, S.; Khadivi, M.A.; Shojaeimehr, T.; Shavisi, Y. Characterization, Isotherm and Kinetic Studies for Ammonium Ion Adsorption by Light Expanded Clay Aggregate (LECA). J. Saudi Chem. Soc. 2016, 20, S342-S351. [CrossRef]

161. Yusof, A.M.; Keat, L.K.; Ibrahim, Z.; Majid, Z.A.; Nizam, N.A. Kinetic and Equilibrium Studies of the Removal of Ammonium Ions from Aqueous Solution by Rice Husk Ash-Synthesized Zeolite Y and Powdered and Granulated Forms of Mordenite. J. Hazard. Mater. 2010, 174, 380-385. [CrossRef]

162. Liu, H.; Dong, Y.; Liu, Y.; Wang, H. Screening of Novel Low-Cost Adsorbents from Agricultural Residues to Remove Ammonia Nitrogen From Aqueous Solution. J. Hazard. Mater. 2010, 178, 1132-1136. [CrossRef] [PubMed]

163. Ji, Z.Y.; Yuan, J.S.; Li, X.G. Removal of Ammonium from Wastewater Using Calcium Form Clinoptilolite. J. Hazard. Mater. 2007, 141, 483-488. [CrossRef] [PubMed]

164. Fiol, N.; Villaescusa, I. Determination of Sorbent Point Zero Charge: Usefulness in Sorption Studies. Environ. Chem. Lett. 2009, 7, 79-84. [CrossRef]

165. Makoto, K.; Koike, T. Charcoal Ecology: Its Function as a Hub for Plant Succession and Soil Nutrient Cycling in Boreal Forests. Ecol. Res. 2021, 36, 4-12. [CrossRef]

166. Andersson, K.I.; Eriksson, M.; Norgren, M. Removal of Lignin from Wastewater Generated by Mechanical Pulping Using Activated Charcoal and Fly Ash: Adsorption Isotherms and Thermodynamics. Ind. Eng. Chem. Res. 2011, 50, 7722-7732. [CrossRef]

167. Gómez-Rey, M.X.; Madeira, M.; Coutinho, J. Wood Ash Effects on Nutrient Dynamics and Soil Properties under Mediterranean Climate. Ann. For. Sci. 2012, 69, 569-579. [CrossRef]

168. Özcan, A.S.; Erdem, B.; Özcan, A. Adsorption of Acid Blue 193 from Aqueous Solutions onto BTMA-Bentonite. Colloids Surfaces A Physicochem. Eng. Asp. 2005, 266, 73-81. [CrossRef]

169. Ho, Y. Review of Second-Order Models for Adsorption Systems. J. Hazard. Mater. 2006, 136, 681-689. [CrossRef] [PubMed]

170. Ruíz-Baltazar, A.; Pérez, R. Kinetic Adsorption Study of Silver Nanoparticles on Natural Zeolite: Experimental and Theoretical Models. Appl. Sci. 2015, 5, 1869-1881. [CrossRef]

171. Ravichandran, J.; Sivasankar, B. Properties and Catalytic Activity of Acid-Modified Montmorillonite and Vermiculite. Clays Clay Miner. 1997, 45, 854-858. [CrossRef]

172. Weber, W.J., Jr.; Morris, J.C. Kinetics of Adsorption on Carbon from Solution. J. Sanit. Eng. Div. 1963, 89, 31-59. [CrossRef]

173. Gürses, A.; Karaca, S.; Doğar, Ç.; Bayrak, R.; Açıkyıldız, M.; Yalçın, M. Determination of Adsorptive Properties of Clay/Water System: Methylene Blue Sorption. J. Colloid Interface Sci. 2004, 269, 310-314. [CrossRef] [PubMed]

174. Özcan, A.; Öncü, E.M.; Özcan, A.S. Adsorption of Acid Blue 193 from Aqueous Solutions onto DEDMA-Sepiolite. J. Hazard. Mater. 2006, 129, 244-252. [CrossRef]

175. Lagergren, S. Zur Theorie der Sogenannten Adsorption Geloster Stoffe. K. Sven. Vetenskapsakademiens. Handl. 1898, $24,1-39$.

176. Sieczka, A.; Koda, E. Kinetic and Equilibrium Studies of Sorption of Ammonium in the Soil-Water Environment in Agricultural Areas of Central Poland. Appl. Sci. 2016, 6, 269. [CrossRef]

177. Yuan, Q.; Li, N.; Chi, Y.; Geng, W.; Yan, W.; Zhao, Y.; Li, X.; Dong, B. Effect of Large Pore Size of Multifunctional Mesoporous Microsphere on Removal of Heavy Metal Ions. J. Hazard. Mater. 2013, 254, 157-165. [CrossRef] [PubMed]

178. Srividya, K.; Mohanty, K. Biosorption of Hexavalent Chromium from Aqueous Solutions by Catla Catla Scales: Equilibrium and Kinetics Studies. Chem. Eng. J. 2009, 155, 666-673. [CrossRef]

179. Abdelnaeim, M.Y.; El Sherif, I.Y.; Attia, A.A.; Fathy, N.A.; El-Shahat, M.F. Impact of Chemical Activation on the Adsorption Performance of Common Reed Towards Cu [II] and Cd [II]. Int. J. Min. Process. 2016, 157, 80-88. [CrossRef] 
180. Zhao, Y.; Zhang, B.; Zhang, X.; Wang, J.; Liu, J.; Chen, R. Preparation of Highly Ordered Cubic NaA Zeolite from Halloysite Mineral for Adsorption of Ammonium Ions. J. Hazard. Mater. 2010, 178, 658-664. [CrossRef] [PubMed]

181. Ravichandran, T.; Arivoli, S. Adsorption of Rhodamine-B from Aqueous Solution by Activated Calcite Powder Studies on Equilibrium Isotherm, Kinetics and Thermodynamics. Int. J. Pollut. Abate. Technol. 2013, 2, 6-12.

182. Ünlü, N.; Ersoz, M. Adsorption Characteristics of Heavy Metal Ions onto a Low Cost Biopolymeric Sorbent from Aqueous Solutions. J. Hazard. Mater. 2006, 136, 272-280. [CrossRef] [PubMed]

183. Hui, K.S.; Chao, C.Y.H.; Kot, S.C. Removal of Mixed Heavy Metal Ions in Wastewater by Zeolite 4A and Residual Products from Recycled Coal Fly Ash. J. Hazard. Mater. 2005, 127, 89-101. [CrossRef] [PubMed]

184. Hale, S.E.; Alling, V.; Martinsen, V.; Mulder, J.; Breedveld, G.D.; Cornelissen, G. The Sorption and Desorption of Phosphate-P, Ammonium-N and Nitrate-N in Cacao Shell and Corn Cob Biochars. Chemosphere 2013, 91, 1612-1619. [CrossRef] [PubMed]

185. Van Erp, T.S.; Martens, J.A. A Standardization for Bet Fitting of Adsorption Isotherms. Microporous Mesoporous Mater. 2011, 145, 188-193. [CrossRef]

186. Mel'gunov, M.S.; Ayupov, A.B. Direct Method for Evaluation of BET Adsorbed Monolayer Capacity. Microporous Mesoporous Mater. 2017, 243, 147-153. [CrossRef]

187. Ambroz, F.; Macdonald, T.J.; Martis, V.; Parkin, I.P. Evaluation of the BET Theory for the Characterization of Meso and Microporous MOFs. Small Methods 2018, 2, 1800173. [CrossRef]

188. Yin, Q.; Zhang, B.; Wang, R.; Zhao, Z. Phosphate and Ammonium Adsorption of Sesame Straw Biochars Produced at Different Pyrolysis Temperatures. Environ. Sci. Pollut. Res. 2018, 25, 4320-4329. [CrossRef] [PubMed]

189. Thommes, M.; Kaneko, K.; Neimark, A.V.; Olivier, J.P.; Rodriguez-Reinoso, F.; Rouquerol, J.; Sing, K.S. Physisorption of Gases, with Special Reference to the Evaluation of Surface Area and Pore Size Distribution (IUPAC Technical Report). Pure Appl. Chem. 2015, 87, 1051-1069. [CrossRef]

190. Karthik, R.M.; Philip, L. Sorption of Pharmaceutical Compounds and Nutrients by Various Porous Low Cost Adsorbents. J. Environ. Chem. Eng. 2021, 9, 104916. [CrossRef]

191. Walton, K.S.; Snurr, R.Q. Applicability of the BET Method for Determining Surface Areas of Microporous Metal-Organic Frameworks. J. Am. Chem. Soc. 2007, 129, 8552-8556. [CrossRef] [PubMed]

192. Machado, A.I.; Dordio, A.; Fragoso, R.; Leitão, A.E.; Duarte, E. Furosemide Removal in Constructed Wetlands: Comparative Efficiency of LECA and Cork granulates as support matrix. J. Environ. Manag. 2017, 203, 422-428. [CrossRef]

193. Lombi, E.; Susini, J. Synchrotron-Based Techniques for Plant and Soil Science: Opportunities, Challenges and Future Perspectives. Plant Soil 2009, 320, 1-35. [CrossRef]

194. Khandaker, S.; Kuba, T.; Toyohara, Y.; Kamida, S.; Uchikawa, Y. Development of Ion-Exchange Properties of Bamboo Charcoal Modified With Concentrated Nitric Acid. In IOP Conference Series: Earth and Environmental Science; IOP Publishing: Bristol, UK, 2017; Volume 82, p. 012002.

195. Mourdikoudis, S.; Pallares, R.M.; Thanh, N.T. Characterization Techniques for Nanoparticles: Comparison and Complementarity upon Studying Nanoparticle Properties. Nanoscale 2018, 10, 12871-12934. [CrossRef] [PubMed]

196. Cai, W.; Li, Z.; Wei, J.; Liu, Y. Synthesis of Peanut Shell Based Magnetic Activated Carbon With Excellent Adsorption Performance Towards Electroplating Wastewater. Chem. Eng. Res. Des. 2018, 140, 23-32. [CrossRef]

197. Cai, W.; Wei, J.; Li, Z.; Liu, Y.; Zhou, J.; Han, B. Preparation of Amino-Functionalized Magnetic Biochar with Excellent Adsorption Performance for Cr (VI) by a Mild One-Step Hydrothermal Method from Peanut Hull. Colloids Surf. A Physicochem. Eng. Asp. 2019, 563, 102-111. [CrossRef]

198. Nabeela, F.; Murad, W.; Khan, I.; Mian, I.A.; Rehman, H.; Adnan, M.; Azizullah, A. Effect of Wood Ash Application on the Morphological, Physiological and Biochemical Parameters of Brassica Napus L. Plant Physiol. Biochem. 2015, 95, 15-25. [CrossRef] [PubMed]

199. Ozolinčius, R.; Varnagiryte, I.; Armolaitis, K.; Karltun, E. Initial Effects of Wood Ash Fertilization on Soil, Needle and Litterfall Chemistry in a Scots Pine [Pinus Sylvestris L.] Stand. Balt. For. 2005, 11, 59-67.

200. Eriksson, H.M.; Nilsson, T.; Nordin, A. Early Effects of Lime and Hardened and Non-Hardened Ashes on pH and Electrical Conductivity of the Forest Floor, an Relations to Some Ash and Lime Qualities. Scand. J. For. Res. Suppl. 1998, 2, 56-66.

201. Mohamed, S.A.; Ewees, S.A.; Sawsan, A.; Seaf, E.Y.; Dalia, M.S. Improving Maize Grain Yield and Its Quality Grown on a Newly Reclaimed Sandy Soil by Applying Micronutrients, Organic Manure and Biological Inoculation. Res. J. Agric. Biol. Sci. 2008, 4, 537-544.

202. Pitman, R.M. Wood Ash Use in Forestry-A Review of the Environmental Impacts. For. An Int. J. For. Res. 2006, 79, 563-588. [CrossRef]

203. Park, B.B.; Yanai, R.D.; Sahm, J.M.; Lee, D.K.; Abrahamson, L.P. Wood Ash Effects on Plant and Soil in a Willow Bioenergy Plantation. Biomass Bioenergy 2005, 28, 355-365. [CrossRef]

204. Etiegni, L.; Campbell, A.G. Physical and Chemical Characteristics of Wood Ash. Bioresour. Technol. 1991, 37, 173-178. [CrossRef]

205. Fritze, H.; Pennanen, T.; Pietikäinen, J. Recovery of Soil Microbial Biomass and Activity from Prescribed Burning. Can. J. For. Res. 1993, 23, 1286-1290. [CrossRef]

206. Martikainen, P.J.; Ohtonen, R.; Silvola, J.; Vuorinen, A. The Effects of Fertilization on Forest Soil Biology. Eff. Fertil. For. Ecosyst. 1994, 1994, 40-79. 
207. Nottfige, D.O.; Ojeniyi, S.O.; Asawalam, D.O. Comparative Effect of Plant Residues and NPK Fertilizer on Nutrient Status and Yield of Maize [Zea Mays L.] in a Humid Ultisol. Niger. J. Soil Sci. 2005, 15, 1-8.

208. Mbah, C.N.; Nwite, J.N.; Njoku, C.; Nweke, I.A. Response of Maize (Zea Mays L.) to Different Rates of Wood-Ash Application in Acid Ultisol in Southeast Niger. Afr. J. Agric. Res. 2010, 5, 580-583.

209. Owolabi, O.; Ojeniyi, S.O.; Amodu, A.O.; Hazzan, K. Response of Cowpea, Okra and Tomato Sawdust Ash Manure. Moor J. Agric. Res. 2003, 4, 178-182. [CrossRef]

210. Perkiömäki, J. Wood Ash Use in Coniferous Forests: A Soil Microbiological Study into the Potential Risk of Cadmium Release. 2004 Available online: https:/ / helda.helsinki.fi/bitstream/handle/10138/20875/woodashu.pdf?sequence=1 (accessed on 1 May 2021).

211. Lundborg, A. Ecological and Economical Evaluation of Biomass Ash Utilization-The Swedish Approach. Ashes and particulate emissions from biomass combustion, Series Thermal Biomass Utilization. Inst. Chem. Engin. Techn. Univ. Graz. 1998, 3, $29-41$.

212. Augusto, L.; Bakker, M.R.; Meredieu, C. Wood Ash Applications to Temperate Forest Ecosystems-Potential Benefits and Drawbacks. Plant Soil 2008, 306, 181-198. [CrossRef]

213. Insam, H.; Franke-Whittle, I.H.; Knapp, B.A.; Plank, R. Use of Wood Ash and Anaerobic Sludge for Grassland Fertilization: Effects on Plants and Microbes. Die Bodenkult. 2009, 60, 39-50.

214. Füzesi, I.; Heil, B.; Kovács, G. Effects of Wood Ash on the Chemical Properties of Soil and Crop Vitality in Small Plot Experiments. Acta Silv. Lignaria Hung. 2015, 11, 55-64. [CrossRef]

215. Arvidsson, H.; Lundkvist, H. Effects of Crushed Wood Ash on Soil Chemistry in Young Norway Spruce Stands. For. Ecol. Manag. 2003, 176, 121-132. [CrossRef]

216. Krevelen, D.W. Coal: Typology, Chemistry, Physics, Constitution; Elsevier Publishing Company: Amsterdam, The Netherlands, 1961.

217. Major, J.; Rondon, M.; Molina, D.; Riha, S.J.; Lehmann, J. Maize Yield and Nutrition during 4 Years after Biochar Application to a Colombian Savanna Oxisol. Plant Soil 2010, 333, 117-128. [CrossRef]

218. Wang, C.; Lu, H.; Dong, D.; Deng, H.; Strong, P.J.; Wang, H.; Wu, W. Insight into the Effects of Biochar on Manure Composting: Evidence Supporting the Relationship between N2O Emission and Denitrifying Community. Environ. Sci. Technol. 2013, 47, 7341-7349. [CrossRef] [PubMed]

219. Cheng, C.H.; Lehmann, J.; Engelhard, M.H. Natural Oxidation of Black Carbon in Soils: Changes in Molecular Form and Surface Charge along a Climosequence. Geochim. Cosmochim. Acta 2008, 72, 1598-1610. [CrossRef]

220. Spokas, K.A.; Novak, J.M.; Masiello, C.A.; Johnson, M.G.; Colosky, E.C.; Ippolito, J.A.; Trigo, C. Physical Disintegration of Biochar: An Overlooked Process. Environ. Sci. Technol. Lett. 2014, 1, 326-332. [CrossRef]

221. Bird, M.I.; Ascough, P.L.; Young, I.M.; Wood, C.V.; Scott, A.C. X-ray Microtomographic Imaging of Charcoal. J. Archaeol. Sci. 2008, 35, 2698-2706. [CrossRef]

222. Hockaday, W.C.; Grannas, A.M.; Kim, S.; Hatcher, P.G. Direct Molecular Evidence for the Degradation and Mobility of BLACK Carbon in Soils from Ultrahigh-Resolution Mass Spectral Analysis of Dissolved Organic Matter from a Fire-Impacted Forest Soil. Org. Geochem. 2006, 37, 501-510. [CrossRef]

223. Kasin, I.; Ohlson, M. An Experimental Study of Charcoal Degradation in a Boreal Forest. Soil Biol. Biochem. 2013, 65, 39-49. [CrossRef]

224. Jaafar, N.M.; Clode, P.L.; Abbott, L.K. Microscopy Observations of Habitable Space in Biochar for Colonization by Fungal Hyphae from Soil. J. Integr. Agric. 2014, 13, 483-490. [CrossRef]

225. Brewer, C.E.; Chuang, V.J.; Masiello, C.A.; Gonnermann, H.; Gao, X.; Dugan, B.; Davies, C.A. New Approaches to Measuring Biochar Density and Porosity. Biomass Bioenergy 2014, 66, 176-185. [CrossRef]

226. Hardie, M.; Clothier, B.; Bound, S.; Oliver, G.; Close, D. Does Biochar Influence Soil Physical Properties and Soil Water Availability? Plant Soil 2014, 376, 347-361. [CrossRef]

227. Gao, X.; Driver, L.E.; Kasin, I.; Masiello, C.A.; Pyle, L.A.; Dugan, B.; Ohlson, M. Effect of Environmental Exposure on Charcoal Density and Porosity in a Boreal Forest. Sci. Total Environ. 2017, 592, 316-325. [CrossRef] [PubMed]

228. Gray, M.; Johnson, M.G.; Dragila, M.I.; Kleber, M. Water Uptake in Biochars: The Roles of Porosity and Hydrophobicity. Biomass Bioenergy 2014, 61, 196-205. [CrossRef]

229. Trubetskaya, A.; Jensen, P.A.; Jensen, A.D.; Glarborg, P.; Larsen, F.H.; Andersen, M.L. Characterization of Free Radicals by Electron Spin Resonance Spectroscopy in Biochars from Pyrolysis at High Heating Rates and at High Temperatures. Biomass Bioenergy 2016, 94, 117-129. [CrossRef]

230. Barnes, R.T.; Gallagher, M.E.; Masiello, C.A.; Liu, Z.; Dugan, B. Biochar-Induced Changes in Soil Hydraulic Conductivity and Dissolved Nutrient Fluxes Constrained by Laboratory Experiments. PLoS ONE 2014, 9, 108-340.

231. Jeffery, S.; Meinders, M.B.; Stoof, C.R.; Bezemer, T.M.; Van De Voorde, T.F.; Mommer, L.; Van Groenigen, J.W. Biochar application Does not Improve the Soil Hydrological Function of a Sandy Soil. Geoderma 2015, 251, 47-54. [CrossRef]

232. Liu, Z.; Dugan, B.; Masiello, C.A.; Barnes, R.T.; Gallagher, M.E.; Gonnermann, H. Impacts of Biochar Concentration and Particle Size on Hydraulic Conductivity and DOC Leaching of Biochar-Sand Mixtures. J. Hydrol. 2016, 533, 461-472. [CrossRef]

233. Warnock, D.D.; Lehmann, J.; Kuyper, T.W.; Rillig, M.C. Mycorrhizal Responses to Biochar in Soil-Concepts and Mechanisms. Plant Soil 2007, 300, 9-20. [CrossRef]

234. Hermann, B.G.; Debeer, L.; De Wilde, B.; Blok, K.; Patel, M.K. To Compost or not to Compost: Carbon and Energy Footprints of Biodegradable Materials' Waste Treatment. Polym. Degrad. Stab. 2011, 96, 1159-1171. [CrossRef] 
235. Masulili, A.; Utomo, W.H.; Syechfani, M.S. Rice Husk Biochar for rice Based Cropping System in Acid Soil 1. The Characteristics of Rice Husk Biochar and Its Influence on the Properties of Acid Sulfate Soils and Rice Growth in West Kalimantan, Indonesia. J. Agric. Sci. 2010, 2, 39. [CrossRef]

236. Lehmann, J.; Rillig, M.C.; Thies, J.; Masiello, C.A.; Hockaday, W.C.; Crowley, D. Biochar Effects on Soil Biota-A Review. Soil Boil. Biochem. 2011, 43, 1812-1836. [CrossRef]

237. Martina, S.M.; Kookana, R.S.; Van Zwieten, L.; Krull, E. Marked Changes in Herbicide Sorption-Desorption Upon Ageing of Biochars in Soil. J. Hazard. Mater. 2012, 231, 70-78. [CrossRef] [PubMed]

238. Tryon, E.H. Effect of Charcoal on Certain Physical, Chemical, and Biological Properties of Forest Soils. Ecol. Monogr. 1948, 18, 81-115. [CrossRef]

239. Gundale, M.J.; DeLuca, T.H. Temperature and Source Material Influence Ecological Attributes of Ponderosa Pine and Douglas-Fir Charcoal. For. Ecol. Manag. 2006, 231, 86-93. [CrossRef]

240. Gundale, M.J.; DeLuca, T.H. Charcoal Effects on Soil Solution Chemistry and Growth of Koeleria Macrantha in the Ponderosa Pine/Douglas-Fir Ecosystem. Biol. Fertil. Soils 2007, 43, 303-311. [CrossRef]

241. Rajkovich, S.; Enders, A.; Hanley, K.; Hyland, C.; Zimmerman, A.R.; Lehmann, J. Corn Growth and Nitrogen Nutrition after Additions of Biochars with Varying Properties to a Temperate Soil. Biol. Fertil. Soils 2012, 48, 271-284. [CrossRef]

242. Ulery, A.L.; Graham, R.C.; Amrhein, C. Wood-Ash Composition and Soil PH Following Intense Burning. Soil Sci. 1993, 156, 358-364. [CrossRef]

243. Brockhoff, S.R.; Christians, N.E.; Killorn, R.J.; Horton, R.; Davis, D.D. Physical and Mineral-Nutrition Properties of Sand-Based Turfgrass Root Zones Amended with Biochar. Agron. J. 2010, 102, 1627-1631. [CrossRef]

244. Biederman, L.A.; Harpole, W.S. Biochar and Its Effects on Plant Productivity and Nutrient Cycling: A meta-Analysis. GCB Bioenergy 2013, 5, 202-214. [CrossRef]

245. Wardle, D.A.; Nilsson, M.-C.; Zackrisson, O. Fire-Derived Charcoal Causes Loss of Forest Humus. Science 2008, $320,629$. [CrossRef] [PubMed]

246. Anderson, C.R.; Condron, L.M.; Clough, T.J.; Fiers, M.; Stewart, A.; Hill, R.A.; Sherlock, R.R. Biochar induced soil microbial community change: Implications for Biogeochemical Cycling of Carbon, Nitrogen and Phosphorus. Pedobiologia 2011, 54, 309-320. [CrossRef]

247. Khodadad, C.L.; Zimmerman, A.R.; Green, S.J.; Uthandi, S.; Foster, J.S. Taxa-Specific Changes in Soil Microbial Community Composition Induced by Pyrogenic Carbon Amendments. Soil Biol. Biochem. 2011, 43, 385-392. [CrossRef]

248. Chen, J.; Sun, X.; Zheng, J.; Zhang, X.; Liu, X.; Bian, R.J.; Li, L.; Cheng, K.; Zheng, J.W.; Pan, G. Biochar Amendment Changes Temperature Sensitivity of Soil Respiration and Composition of Microbial Communities 3 Years after Incorporation in an Organic Carbon-Poor Dry Cropland Soil. Biol. Fertil. Soils 2018, 54, 175-188. [CrossRef]

249. Liang, B.; Lehmann, J.; Sohi, S.P.; Thies, J.E.; O’Neill, B.; Trujillo, L.; Gaunt, J.; Solomon, D.; Grossman, J.M.; Neves, E.G.; et al. Black Carbon Affects the Cycling of Non-Black Carbon in Soil. Org. Geochem. 2010, 41, 206-213. [CrossRef]

250. Qiu, Y.; Cheng, H.; Xu, C.; Sheng, G.D. Surface Characteristics of Crop-Residue-Derived Black Carbon and Lead [II] Adsorp-Tion. Water Res. 2008, 42, 567-574. [CrossRef] [PubMed]

251. Wang, Y.; Zhang, L.; Yang, H.; Yan, G.; Xu, Z.; Chen, C.; Zhang, D. Biochar Nutrient Availability Rather than Its Water Holding Capacity Governs the Growth of Both C3 and C4 Plants. J. Soils Sediments 2016, 16, 801-810. [CrossRef]

252. Prendergast-Miller, M.T.; Duvall, M.; Sohi, S.P. Localisation of Nitrate in the Rhizosphere of Biochar-amended Soils. Soil Biol. Biochem. 2011, 43, 2243-2246. [CrossRef]

253. Gul, S.; Whalen, J.K.; Thomas, B.W.; Sachdeva, V.; Deng, H. Physico-Chemical Properties and Microbial Responses in Bio-CharAmended Soils: Mechanisms and Future Directions. Agric. Ecosyst. Environ. 2015, 206, 46-59. [CrossRef]

254. Pietikäinen, J.; Kiikkilä, O.; Fritze, H. Charcoal as a Habitat for Microbes and Its Effect on the Microbial Community of the Underlying Humus. Oikos 2000, 89, 231-242. [CrossRef]

255. Makoto, K.; Tamai, Y.; Kim, Y.S.; Koike, T. Buried Charcoal Layer and Ectomycorrhizae Cooperatively Promote the Growth of Larix Gmelinii Seedlings. Plant Soil 2010, 327, 143-152. [CrossRef]

256. Haider, G.; Steffens, D.; Müller, C.; Kammann, C.I. Standard Extraction Methods May Underestimate Nitrate Stocks Captured by Field-Aged Biochar. J. Environ. Qual. 2016, 45, 1196-1204. [CrossRef]

257. Noel, J.D.; Biswas, P.; Giammar, D.E. Evaluation of a Sequential Extraction Process Used for Determining Mercury Binding Mechanisms to Coal Combustion Byproducts. J. Air Waste Manag. Assoc. 2007, 57, 856-867. [CrossRef] [PubMed]

258. Gierak, A.; Łazarska, I. Adsorption of Nitrate, Nitrite, and Ammonium Ions on Carbon Adsorbents. Adsorpt. Sci. Technol. 2017, 35, 721-727. [CrossRef]

259. Figueiredo, J.L.; Pereira, M.F.R.; Freitas, M.M.A.; Orfao, J.J.M. Modification of the Surface Chemistry of Activated Carbons. Carbon 1999, 37, 1379-1389. [CrossRef]

260. Karhu, K.; Mattila, T.; Bergström, I.; Regina, K. Biochar Addition to Agricultural Soil Increased CH4 Uptake and Water Holding Capacity-Results from a Short-Term Pilot Field Study. Agric. Ecosyst. Environ. 2011, 140, 309-313. [CrossRef]

261. Jankowska, H. (Ed.) Adsorpcja jonów na węglu aktywnym; Naukowe PWN: Warsaw, Poland, 1991.

262. Freddo, A.; Cai, C.; Reid, B.J. Environmental Contextualisation of Potential Toxic Elements and Polycyclic Aromatic Hydrocarbons in Biochar. Environ. Pollut. 2012, 171, 18-24. [CrossRef] [PubMed] 
263. Méndez, A.; Gómez, A.; Paz-Ferreiro, J.; Gascó, G. Effects of Sewage Sludge Biochar on Plant Metal Availability after Application to a Mediterranean Soil. Chemosphere 2012, 89, 1354-1359. [CrossRef] [PubMed]

264. Farrell, M.; Rangott, G.; Krull, E. Difficulties in Using Soil-Based Methods to Assess Plant Availability of Potentially Toxic Elements in Biochars and Their Feedstocks. J. Hazard. Mater. 2013, 250, 29-36. [CrossRef] [PubMed]

265. Chen, T.; Zhang, Y.; Wang, H.; Lu, W.; Zhou, Z.; Zhang, Y.; Ren, L. Influence of Pyrolysis Temperature on Characteristics and Heavy Metal Adsorptive Performance of Biochar Derived from Municipal Sewage Sludge. Bioresour. Technol. 2014, 164, 47-54. [CrossRef]

266. Keiluweit, M.; Kleber, M.; Sparrow, M.A.; Simoneit, B.R.; Prahl, F.G. Solvent-Extractable Polycyclic Aromatic Hydrocarbons in Biochar: Influence of Pyrolysis Temperature and Feedstock. Environ. Sci. Technol. 2012, 46, 9333-9341. [CrossRef]

267. Lyu, H.; He, Y.; Tang, J.; Hecker, M.; Liu, Q.; Jones, P.D.; Codling, G.; Giesy, J.P. Effect of Pyrolysis Temperature on Potential TOXICITY of biochar If Applied to the Environment. Environ. Pollut. 2016, 218, 1-7. [CrossRef] [PubMed]

268. Hale, S.E.; Lehmann, J.; Rutherford, D.; Zimmerman, A.R.; Bachmann, R.T.; Shitumbanuma, V.; O’Toole, A.; Sundqvist, K.L.; Arp, H.P.H.; Cornelissen, G. Quantifying the Total and Bioavailable Polycyclic Aromatic Hydrocarbons and Dioxins in Biochars. Environ. Sci. Technol. 2012, 46, 2830-2838. [CrossRef] [PubMed]

269. Shackley, S.; Carter, S.; Knowles, T.; Middelink, E.; Haefele, S.; Sohi, S.; Cross, A.; Haszeldine, S. Sustainable Gasification-Biochar Systems? A Case-Study of Rice-Husk Gasification in Cambodia, Part I: Context, Chemical Properties, Environmental and Health and Safety Issues. Energy Policy 2012, 42, 49-58. [CrossRef]

270. Mohammadi, A.; Cowie, A.L.; Mai, T.L.A.; Brandao, M.; De La Rosa, R.A.; Kristiansen, P.; Joseph, S. Climate-Change and Health Effects of Using Rice Husk for Biochar-Compost: Comparing Three Pyrolysis Systems. J. Clean. Prod. 2017, 162, 260-272. [CrossRef]

271. Anyanwu, I.N.; Alo, M.N.; Onyekwere, A.M.; Crosse, J.D.; Nworie, O.; Chamba, E.B. Influence of Biochar Aged in Acidic soil on Ecosystem Engineers and Two Tropical Agricultural Plants. Ecotoxicol. Environ. Saf. 2018, 153, 116-126. [CrossRef] [PubMed]

272. Zheng, J.; Chen, J.; Pan, G.; Liu, X.; Zhang, X.; Li, L.; Jinwei, Z. Biochar Decreased Microbial Metabolic Quotient and Shifted Community Composition Four Years after a Single Incorporation in a Slightly Acid Rice Paddy from Southwest China. Sci. Total. Environ. 2016, 571, 206-217. [CrossRef]

273. Safaei Khorram, M.; Fatemi, A.; Khan, M.A.; Kiefer, R.; Jafarnia, S. Potential Risk of Weed Outbreak by Increasing Biochar's Application Rates in Slow-Growth Legume, Lentil (Lens Culinaris Medik.). J. Sci. Food Agric. 2018, 98, 2080-2088. [CrossRef] [PubMed]

274. Ukalska-Jaruga, A.; Debaene, G.; Smreczak, B. Particle and Structure Characterization of Fulvic Acids from Agricultural soils. J. Soils Sediments 2018, 18, 2833-2843. [CrossRef]

275. Chang, R.R.; Mylotte, R.; Hayes, M.H.B.; Mclnerney, R.; Tzou, Y.M. A Comparison of the Compositional Differences between Humic Fractions Isolated by the IHSS and Exhaustive Extraction Procedures. Naturwissenschaften 2014, 101, 197-209. [CrossRef] [PubMed]

276. Sposito, G. The Chemistry of Soils; Oxford University Press: Oxford, UK, 2008.

277. Liu, M.; Wang, C.; Wang, F.; Xie, Y. Maize (Zea Mays) Growth and Nutrient Uptake Following Integrated Improvement of Vermicompost and Humic Acid Fertilizer on Coastal Saline Soil. Appl. Soil Ecol. 2019, 142, 147-154. [CrossRef]

278. Ali, J.; Li, Y.; Wang, X.; Zhao, J.; Xi, N.; Zhang, Z.; Xia, X. Climate-Zone-Dependent Effect Mechanism of Humic Acid and Fulvic Acid Extracted from River Sediments on Aggregation Behavior of Graphene Oxide. Sci. Total Environ. 2020, 721, 137-682. [CrossRef] [PubMed]

279. Ahmad, I.; Ali, S.; Khan, K.S.; Hassan, F.U.; Ijaz, S.S.; Bashir, K. Use of Coal Derived Humic Acid as Soil Conditioner for Soil Physical Properties and Its Impact on Wheat Crop Yield. Int. J. Biosci. 2015, 6, 81-89.

280. Gholami, H.; Fard, F.R.; Saharkhiz, M.J.; Ghani, A. Yield and Physicochemical Properties of Inulin Obtained from Iranian Chicory Roots under Vermicompost and Humic Acid Treatments. Ind. Crop. Prod. 2018, 123, 610-616. [CrossRef]

281. Turgay, O.C.; Karaca, A.; Unver, S.; Tamer, N. Effects of Coal-Derived Humic Substance on Some Soil Properties and Bread Wheat Yield. Commun. Soil Sci. Plant Anal. 2011, 42, 1050-1070. [CrossRef]

282. Zhang, S.Q.; Liang, Y.; Wei, L.; Lin, Z.A.; Li, Y.T.; Hu, S.W.; Zhao, B.Q. Effects of Urea Enhanced with Different Weathered Coal-derived Humic Acid Components on Maize Yield and Fate of Fertilizer Nitrogen. J. Integr. Agric. 2019, 18, 656-666. [CrossRef]

283. Jin, J.; Sun, K.; Yang, Y.; Wang, Z.; Han, L.; Wang, X.; Wu, F.; Xing, B. Comparison between Soil-And Biochar-Derived Humic acids: Composition, Conformation, and Phenanthrene Sorption. Environ. Sci. Technol. 2018, 52, 1880-1888. [CrossRef]

284. Schnitzer, M.; Skinner, S.I.M. Alkali versus Acid Extraction of Soil Organic Matter. Soil Sci. 1968, 105, 392-396. [CrossRef]

285. Schnitzer, M. Humic Substances: Chemistry and Reactions. In Developments in Soil Science; Elsevier: Amsterdam, The Netherlands, 1978; Volume 8, pp. 1-64.

286. Schaumann, G.E. Soil Organic Matter beyond Molecular Structure Part I: Macromolecular and Supramolecular Characteristics. J. Plant Nutr. Soil Sci. 2006, 169, 145-156. [CrossRef]

287. Schaumann, G.E. Soil Organic Matter beyond Molecular Structure Part II: Amorphous Nature and Physical Aging. J. Plant Nutr. Soil Sci. 2006, 169, 157-167. [CrossRef]

288. Tan, K.H. Humic Matter in Soil and the Environment: Principles and Controversies; CRC Press: Boca Raton, FL, USA, 2014. 
289. Hayes, M.H.; Mylotte, R.; Swift, R.S. Humin: Its Composition and Importance in Soil Organic Matter. Adv. Agrono. 2017, 143, 47-138.

290. Lehmann, J.; Kleber, M. The Contentious Nature of Soil Organic Matter. Nature 2015, 528, 60-68. [CrossRef] [PubMed]

291. Contreras, C.; De La Rosa, G.; Peralta-Videa, J.R.; Gardea-Torresdey, J.L. Lead Adsorption by Silica-Immobilized Humin under Flow and Batch Conditions: Assessment of Flow Rate and Calcium and Magnesium Interference. J. Hazard. Mater. 2006, 133, 79-84. [CrossRef] [PubMed]

292. Li, S.; Li, D.; Li, J.; Li, G.; Zhang, B. Evaluation of Humic Substances during Co-Composting of Sewage Sludge and Corn Stalk under Different Aeration Rates. Bioresour. Technol. 2017, 245, 1299-1302. [CrossRef] [PubMed]

293. Pan, W.L.; Port, L.E.; Xiao, Y.; Bary, A.I.; Cogger, C.G. Soil Carbon and Nitrogen Fraction Accumulation with Long-Term Biosolids Applications. Soil Sci. Soc. Am. J. 2017, 81, 1381. [CrossRef]

294. Wang, Y.; Zheng, J.; Liu, X.; Yan, Q.; Hu, Y. Short-Term Impact of Fire-Deposited Charcoal on Soil Microbial Community Abundance and Composition in a Subtropical Plantation in China. Geoderma 2020, 359, 113992. [CrossRef]

295. Bremner, J.M. Studies on Soil Organic Matter: Part I. The Chemical Nature of Soil Organic Nitrogen. J. Agric. Sci. 1949, 39, 183-193. [CrossRef]

296. Plante, A.F.; Conant, R.T.; Paul, E.A.; Paustian, K.; Six, J. Acid Hydrolysis of Easily Dispersed and Microaggregate-Derived Silt-and Clay-Sized Fractions to Isolate Resistant Soil Organic Matter. Eur. J. Soil Sci. 2006, 57, 456-467. [CrossRef]

297. Martel, Y.A.; Paul, E.A. The Use of Radiocarbon Dating of Organic Matter in the Study of Soil Genesis. Soil Sci. Soc. Am. J. 1974, 38, 501-506. [CrossRef]

298. Schnitzer, M.; Preston, C.M. Effects of Acid Hydrolysis on the 13 C NMR Spectra of Humic Substances. Plant Soil 1983, 75, 201-211. [CrossRef]

299. Helfrich, M.; Flessa, H.; Mikutta, R.; Dreves, A.; Ludwig, B. Comparison of Chemical Fractionation Methods for Isolating Stable Soil Organic Carbon Pools. Eur. J. Soil Sci. 2007, 58, 1316-1329. [CrossRef]

300. Pessenda, L.C.; Gouveia, S.E.; Aravena, R. Radiocarbon Dating of Total Soil Organic Matter and Humin Fraction and Its Comparison with 14C Ages of Fossil Charcoal. Radiocarbon 2001, 43, 595-601. [CrossRef]

301. Sun, X.; Zhong, T.; Zhang, L.; Zhang, K.; Wu, W. Reducing Ammonia Volatilization from Paddy Field with Rice Straw Derived Biochar. Sci. Total. Environ. 2019, 660, 512-518. [CrossRef] [PubMed] 